Sinop Üniversitesi

Sosyal Bilimler Dergisi

Araştırma Makalesi
Sinop Üniversitesi Sosyal Bilimler Dergisi, 3 (1): 115-142

Geliş Tarihi:03.01.2019

Kabul Tarihi:17.06.2019

https://doi.org/10.30561/sinopusd.507453

https://dergipark.org.tr/sinopusd

\title{
BAFRA KIRSAL KONUTLARINDA ÇIKMALAR
}

\section{Şerif TÜMER*}

\section{$\ddot{O}_{z}$}

Çıkmalı ev mimarisi, Türk sivil mimarlığının temel unsurlarından birisi belki de en karakteristik özelliğidir. Gerek imparatorluk başkenti İstanbul'da gerekse Anadolu'nun birçok yerinde çıkmalı evlere rastlamak mümkündür. Fakat kırsal mimari özelinde hatta dağ köylerinde çıkmalı (cumbalı) ev mimarisine rastlanması, büyük kentler ölçeğindeki Türk sivil mimarlığı zevkinin, Anadolu kırsalındaki yansıması olarak karşımıza çıkmaktadır. Mahrem unsur olan ev içinin kent mimarlığında dışarıya açılmasını sağlayan, cephenin hareketlendirilmesi amacının yanı sıra manzara arayışının bir sonucu olan çıkmaların kırsal bölgelerde karşımıza çıkması Anadolu kırsal mimarlığında işlevselliğin yanı sıra beğeni arayışının da net bir göstergesidir. Karadeniz bölgesinin karakteristik malzemesi ahşap da dâhil olmak üzere çeşitli malzemelerden yapılan Bafra köy evlerindeki çıkmalar bu çalışmanın konusu olacaktır. $\mathrm{Bu}$ çıkmalar konum, malzeme, strüktür gibi yönlerden incelenerek önemleri ortaya konulacaktır. 8 köyden 32 evin inceleneceği bu çalışmayla Bafra kırsal konut çıkma türleri belirlenecek olup Anadolu kır konutları arasındaki yeri ve önemi belirtilecektir. Böylelikle bu konu üzerine çalışan araştırmacılar için bir kaynak görevi görecektir. Şehir evlerinde sıkça karşımıza çıkan ve uygun olmayan arazi şartlarında üst kat plânını düzeltmek amaçlı başvurulan kat çıkmalarının Bafra köy evlerinde çok sık görülmemesi, köylerdeki geniş ve uygun arazi şartlarında bu kullanıma gerek duyulmamasından kaynaklıdır. Yine özellikle kent mimarlığında karşımıza çıkan sofa

\footnotetext{
* Arş. Gör., Mardin Artuklu Ünv.Edebiyat Fak. Sanat Tarihi Böl., seriftumer@artuklu.edu.tr, https://orcid.org/0000-0002-0108-9647.
} 
çıkmalı köy evlerinin Bafra kırsal mimarlığında sıkça uygulanması Bafra köy evlerinde beğeninin, işlevselliğin önüne geçtiğinin göstergesidir. Bu makale "Bafra Kırsal Mimarisi”, isimli ve hâlen yazım aşamasında olan doktora tezi kapsamında yazılmıştır.

Anahtar kelimeler: Bafra, Kırsal mimari, Çıkma, Köy evi, Cumba.

\title{
Projections Rural House in the Bafra
}

\begin{abstract}
Projections house architecture (home architecture of the Bay) one of the basic elements of Turkish Civil Architecture is probably one of the most characteristic features. Oriel house architecture (bay window, oriel, projection) is possible to come across both in the imperial capital of Istanbul and in many parts of Anatolia. However, rural architecture even in mountains villages run across is a reflection of Turkish civil architectural pleasure in Anatolia countryside of large cities scale. It is clear that indication of the aesthetic research as well as functionality in the rural architecture of Anatolia, in addition to the purpose of activating house's inner area which is the outcome of the search for this landscape. In this study, subject will be the characteristics of the Black Sea region involve in the wooden materials from varies village houses made of elements in the village of Bafra. These oriels (bay window) by researching their significance will be revealed in terms of location, elements, structure. This study, in which 32 houses from 8 villages will be examined, will determine the types of rural housing types in Bafra and its importance and place among the Anatolian country houses. Thus, it will serve as a reference for researchers who work on this subject. The bay window, which is frequently encountered in urban houses and used in order to correct the upper floor plan in unsuitable land conditions are not seen very often for the Bafra village houses, due to large and suitable land conditions in the villages. Especially, sofa bay houses which are used in the urban architecture are used very often in the rural architecture of Bafra is an indicator that liking is more important than functionality. This article was produced from a $\mathrm{PhD}$ thesis that is on still writing process and its name is "Rural Architecture of Bafra".
\end{abstract}

Keywords: Bafra, Rural architecture, Oriel, Rural house, projection. 


\section{Giriş}

Ülkemizin en önemli ovalarından birisine sahip olan Bafra, tarihi ve mimari anlamda ön plana çıkan bir yerleşimdir. Birçok ilden daha büyük bir ilçe olan Bafra ova olma özelliğinden de kaynaklı olarak 132 köye sahiptir. Bu köylerin büyük çoğunluğu ova köyüdür. Geleneksel dokuya genellikle yüksek ve şehir merkezine uzak olan dağ köylerinde daha çok rastlamaktayı. Bu husus araştırılması gereken ayrı bir konu olarak karşımıza çıkmaktadır. Bafra ova köylerinde çiftçilik ve hayvancıllı̆̆n yapılabilmesine paralel olarak elde edilen maddi güç, yine bu ekonomik faaliyetlere bağlı olarak gelişen karayolu ağı, ulaşımı kolaylaştırmış olup köylerdeki modern olarak tabir edilen ev mimarisinin gelişmesine zemin hazırlamıştır. Dağ köylerinden de geleneksel konutların terk edilip modern evlerin inşa edilmeye başlandığının tespiti ivedilikle bu konuya eğilmemize neden olmuştur. Bu nedenle dağ köylerinde mevcut olan, yörenin geleneksel konut mimarisini yansitan örneklerin tespit edilerek kayıt altına alınması, bu evlerin belgelenmesi açısından oldukça önem taşımaktadır. $\mathrm{Bu}$ noktada neden kentsel değil de kırsal ev mimarisi çalıştı̆̆ımız sorusunun cevabı da kendiliğinden ortaya çıkacaktır.

Bafra şehir merkezi ile deniz arasında yer alan ve ova köyleri diyebileceğimiz köylerde geleneksel doku adına bir şey kaldığı söylenemez. Hatta bu modern mimari ile yapılan köy evlerinin dış cephelerinde mantolama sisteminin yer alması durumun vahametini göstermesi adına ilginçtir. Bu nedenle çalışmamız ağırlıklı olarak Bafra'nın güneyinde yoğunlaşmıştır. Bu bölge Derbent Barajı civarı ve daha da yukarısında yer alan köylerden oluşmaktadır. Çalışma kapsamında 8 köyden tespit edilen 33 adet ev incelenecektir. İleride detaylı bilgi verilecek olan bu köyler: Kolay, Şahinkaya, Kuzalan, Terzili, Bengü, Çulhakoca, Karakütük ve Meşelitürkmenler köyleridir.

Çalışmamızda Bafra kırsalında yer alan çıkmaları malzeme, teknik, konumlandırılış vb. unsurlar açısından ele alacağız. Türk Evi'nin temel unsurlarından olan çıkmalar daha çok kent mimarlığında, zengin evleri olarak nitelendirilen ko- 
nutlarda karşımıza çıkmaktadır. Konutta çıkma dediğimiz zaman aklımıza köşe çıkması, kat çıkması, gönyeli çıkma gibi çıkma türleri aklımıza gelir. Bunların içerisinde oldukça önemli yere sahip olan sofa çıkmalarının (cumba) köy evlerinde karşımıza çıkması, kırsal mimaride beğeni ve işlevsellik arayışlarının sonucu olmalıdır. Bu çalışamada Arapça kökenli “'Cumba” terimi yerine Türkçe karşılığı olan "Çıkma" terimi yeğlenmiş ve kullanılmıştır.

\section{Bafra'nın Coğrafi Konumu ve Tarihçesi}

Karadeniz Bölgesi'nin orta kısmında yer alan Bafra, Samsun iline bağlı bir ilçedir. Türkiye'nin en önemli ovalarından olan Bafra $41^{\circ}$ ve $33.0^{\prime}$ kuzey paralelleri ile $35^{\circ}$ ve 54.0' doğu meridyenleri arasında yer almaktadır (Özkan, 2012: 9). Yaklaşı 143.000 nüfusa sahip olan Bafra batı yönde Alaçam, doğuda 19 Mayıs ilçesi ve Samsun il merkezi, kuzeyde Karadeniz, güneyde ise Kavak, Havza ve Vezirköprü ilçeleri tarafindan çevrelenmiştir.

Sivas'tan doğan Kızılırmak Bafra'da Karadeniz'e dökülmektedir. Kızılırmak Nehri'nin oluşturduğu verimli alüvyon toprakları üzerinde yer alan Bafra, Türkiye'nin sayılı ve en önemli ovalarından biridir. Tüm y1l boyunca mahsül yetiştirilebilen Bafra'da tarım ve hayvancılık temel geçim kaynağıdır. Nüfusun yaklaşık olarak yarısı köylerde yaşamakta olup bu köylerin çoğu ova köyleridir. Bafra ilçesi (Harita 1) tütün üretiminde de ön plana çıkmış olup bu konuda Türkiye'de hatırı sayılır bir yere sahiptir.

Bafra ilçe merkezi ile Karadeniz arasındaki bölge ve Derbent Barajı'na kadar olan kısım ova köyleri olarak nitelendirilebilecek, düz ve tarıma elverişli yerleşimlerdir. Ancak Altınkaya Barajı’ndan sonra yükselti başlayacak ve dağ köyleri dediğimiz yerleşimler karşımıza çıkacaktır (Harita 2). Bu bölgede topoğrafik şartlardan dolayı hayvancılık ön plana çıkmıştır. Bafra'nın güneyindeki yükseltinin nedeni olan Canik ve Küre Dağları, Kızılırmak tarafından birbirlerinden ayırılır. Böylece bu dağların doğal sınırları da belirlenmiş olur. 
İklimin oluşumunu etkileyen birçok etken etken vardır. Bunlar coğrafi durum (dağların uzanış yönleri, bitki örtüsü), şehrin denize yakın veya uzaklığı, yeryüzü şekiller, bakı ve yükseltidir (Küçük, 2018: 32). Ülkemiz orta kuşakta ve çeşitli iklimlerim görülüğü bir coğrafya yer alır (Küçük, 2018: 32). Bafra ise Türkiye'nin kuzeyinde Karadeniz Bölgesi'nin orta kısmında konumlanır. Dağlar Karadeniz bölgesinin doğusunda hemen hemen deniz kenarından yükseldiği halde, Ordu'dan sonra Çarşamba, Samsun ve Bafra'nın güney hattından denizin daha gerisinden yükselmeye başlar (Tuna, 2009: 18).

Karadeniz iklimi: her mevsimi yağışlı, en fazla yağışın sonbaharda görüldüğü, nem oranı fazla olan ve buna bağlı gür bitki örtüsüne sahip bir iklim tipidir. Bafra bu noktada Karadeniz ikliminden bazı farklılıklar gösterir. Bunun başında yağış miktarı gelmekte olup Bafra, Karadeniz ikliminin görüldüğü yerlerden yağış olarak daha düşük bir orana sahiptir (Küçük, 2018: 32). Bafra'nın nisbi nem ortalaması $\% 73$ olup özellikle nisan ve mayıs aylarında bu oran $\% 80$ lere ulaşır.

Arkeolojik buluntular göz önüne alındığında Bafra'nın en az beş bin yıllık bir geçmişi vardır. Birçok medeniyete ev sahipliği yapmış olan Bafra'da sırasıyla Hititler (M.Ö. 1650-1200), Pontus Krallı̆̆1 (M.Ö. 302-71), Bizans (395-1086) gibi devletler varlık göstermiştir (Özkan, 2012: 10).

Malazgirt Zaferi’nin ardından yoğun bir nüfusla Anadolu'ya giren Türk beyleri Karadeniz içlerine kadar sokulmuştur (Özkan, 2012, 11). Bu akınlarla birlikte Türk kültürü Anadolu'da yerleşmeye başlamıştır. Öyle ki Canik ismine Türklerin Anadolu'ya gelmesinden sonra rastlamaktayız (Özkan, 2012: 10-11). 12. yüzyılda Danişmendli akınlarına direnen Bafra 1214'te II. İzzeddin Keykâvus tarafından alınmıştır (Öz, 1999: 19). 13. yüzyılda Sinop merkezli Pervaneoğulları Beyliği denetimine giren Bafra 14. yüzyılda Bavra (Bafra) Beyliği’nin kontrolü altına girmiştir (Özkan, 2012: 11).

1396 yılında Yıldırım Bayezid tarafından Osmanlı Devletine katılan Bafra, Ankara Savaşı sonrasında kısa süre elden çıksa da 1419'da Çelebi Mehmed 
tarafindan tekrar kontrol altına alınarak Cumhuriyet'e dek Osmanlı kontrolünde kalmıştır (Özkan, 2012: 12).

\section{Tarihi Kayıtlarda Bafra'nın Kır Yerleşmeleri ve Nüfus Özellikleri}

Bafra'nın nüfus kayıtlarına 1485 yılından itibaren ulaşılabilmekte olup aynı sene içerisinde iki Müslüman Mahallesi (Mescid-i Cami-i Emirza Bey ve Hüseyin Debbâğ) bulunduğu ve bunlara 1485-1520 yılları arasında Hacı Çırak, Hacı Ahmed, Debbağhâne (Tabakhâne), Ishaklu ile Hoca Sinan Mahalleleri eklendiği ifade edilmektedir. (Özkan, 2012: 19). 1835 tarihli ve 972 numaralı Bafra Müslim defteri verilerine göre Bafra nüfusu 447 haneye dağılmış 1087 kişi olarak belirlenmiş olup Bafra merkeze bağl1 11 mahalle bulunmaktaydı (Özkan, 2012: 20).

15 ve 16. yüzyıllarda Bafra'ya bağlı çeşitli köyler (karyeler) ve bu köylerin kapsadığı alanlar vardı (Özkan, 2012: 20). Kayıtlarda 1576 yılında 138, 1642 yılında ise 110 köy kayıtlıdır (Özkan, 2012: 21). Bunlardan Nahiye-i Üskübi, çoğu günümüze ulaşamayan köylerden (Ada, Döğsire, Ercük, Gerçeme, Hacılar, İmanlı, Kavala, Kışla, Mengiz, Övünç, Üskübi) meydana gelmekte ve Bafra'nın kuzeyinde yer almaktaydı (Özkan, 2012: 20).

Nahiye-i Martıkale Kızılırmak'ın doğu kıyısında yer almakta ve Martıkale'den kuzeye doğru uzanmaktaydı (Özkan, 2012: 20). Kanımızca Martıkale ismi daha sonraları Martala olmuş olan günümüzün Doğankaya Köyü ve civarıdır. Çünkü Nahiye-i Martıkale bünyesindeki yerleşme isimlerine bakıldığında (Bayat, Buryaz, Gaydalapa/Sarıçevre, Girne, İskilip, Kilise, Martakale, Sevinç, Şehevren köyleri) bu yerleşim yerlerinden olan Gaydalapa/Sarıçevre, Martala/Doğankaya, Girne gibi yerleşim isimlerinin günümüzde de varllğııı sürdürdüğü görülür. Yine Şehevren olarak verilen yerleşim yerinin, günümüzün Şeyhören Köyü'nün olması ihtimali söz konusudur.

Emlak Nahiyesi/Boğazkaya Bucağı, Nahiye-i Martıkale'nin güneyinde yer almakta olup içerdiği yerleşim isimlerine bakıldığında (Özkan, 2012: 20) (Alanınkiras, Ayazma, Balcı Boyalıca, Cevrek, Diğer Gaypala, İnözü, Kızıllı, Korvaz, Mz. 
Kulağuz, Tosköy, Şeyhulaş) İnözü Köyü, günümüzün İnözükoşaca Köyü olarak karşımıza çıkar. Tosköy ve Şeyhulaş köyleri ise günümüzde de mevcudiyetini koruyan köylerdir.

Kızılırmağın batısında kuzeyden güneye: Harıs, Pazarlı, Değirmenözü nahiyeleri yer almaktaydı (Özkan, 2012: 20). Harıs nahiyesi günümüzde de ismi kullanılan köyleri bünyesinde toplamış (Asar, Beyköy, Harıs, Bıçaklı, Barunca, Elyakut/Eldavut, Evliya, İnişdibi, Karaburç, Kuşçular, Marezpabi, Arapşah, Oba, Okçular, Övaz maa İnediken, Salubükü, Selamünaleyk/Selemelik, Suçatı, Mardar, İğdir) ve Kızılırmak'ın batı kıyısı boyunca uzanmıştır (Özkan, 2012, 20). Harıs'ın batısında yer alan Pazarlı Nahiyesi: Akçay, Akgüney, Azay, Azaycık, Çorak maa İkipınar, Elmaköy, Emenli, Gelement, Furundar, Gelemare/Koruluk, Gulam, Bengilü/Bengü, Bozkavak, Kanlıcak, Kayalı, Kolay, Mandırçay, Müstecaplu, Övünçbaba, Pelitbükü, Şeyh Miskince, Taşkelik, Yağıbasan, Yenice köylerini kapsarken Nahiye-i Değirmenözü: Paşa (Paşaşeyh), Demşek, Dikenlüce, Elmacık, Gazilü, Gökeçesu, İkizlü, İlyaslu, Oğlakalan, Türk Obas1/Türk Köyü, Virancık/Örencik ve Zeytun köylerini sınırları içine almaktaydı (Özkan, 2012: 21).

1642 senesinde Üskübi, Değirmenözü ve Ayazma nahiyeleri Bafra kazası sınırlarındaydı. Üskübi Nahiyesi Bafra'nın yakın çevresi ile kuzeyindeki ova köylerini, Ayazma nahiyesi Kızılırmak'ın doğusunda kalan bölgeyi, Değirmenözü Nahiyesi ise Kızılırmak'ın batısında kalan köyleri içermekteydi (Özkan, 2012, 21).

1576 ve 1642 seneleri arasında Bafra'nın köy ve hane sayıları tablo (Tablo 1) üzerindeki (Özkan, 2012, 21) gibidir. 1642 senesinde Bafra'nın köy sayısındaki düşüşün (Tablo 2) en önemli nedeninin daha önce Bafra'ya bağlı olan 18 köyün Alaçam'a bağlanması olduğu düşünülmektedir (Özkan, 2012, 21).

1837 tarihine dair detaylı bilgiler veren bir diğer kaynak ise Defteri Liva-1 Canik’tir (Erler, 2009: 177). Bölgedeki nüfus hareketleriyle ilgili bilgiler veren defterde Bafra'nın köyleri hakkında da bilgilere yer verilmiştir. 


\section{Türk Evinde Çıkma}

Sözlük anlamı olarak barınak, çadır (Bozkurt, 1995: 502) ve içinde ailenin barındığı konut (Sözen \& Tanyeli, 2003: 80) anlamları içerin ev, tarih boyunca insanlığın barınma gereksinimi başta olmak üzere sosyal vb. ihtiyaçların görüldüğü ve her kültürün kendine özgü üslûbuyla inşa ettiği mimari birimdir.

Türk Evi'nin zemininden çatısına dek kendine ait, onu tanımlayan bir üslûbu (Eldem, 1984:1-40: Cansever, 2002: 313-320; Aslanapa, 2004, 597-613, Bektaş 200730-169, 164-169) vardır. Çıkma da bunlardan birisi belki de en karakteristiğidir. Çıkma terimi sözlük anlamı olarak "yapının zemin katının üstündeki katta yer alıp sokağa doğru uzanan çıkmalı oda" (Sözen \& Tanyeli, 2003: 54), "bina zemininin üstündeki katlardan oda veya sofanın bina esas bedeninden sokağa doğru taşmış, üstü ve etrafi örtülü biçimine denir', (Çetin, 2006: 19), “sokağa bakabilmek için yapılmış üç tarafı kafesli pencerelerle çevrili ve üstü kapalı balkon'” (Akın, 1995, 509) gibi tanımlarla karşımıza çıkmaktadır.

Çıkma'nın Türk evindeki işlevi üzerine çeşitli fikirler öne sürülmüştür. Çıkma'nın özellikle düzgün olmayan arazi şartlarında evin üst katının düzgün bir plân özelliği arz etmesi amaçlı düzenlendiği fikri ağırlık kazanmaktadır (Evren, 1957: 6-7; Çetin, 2006: 18; Akın,1995: 509; Başkan, 2008: 47). Mesut Evren çıkmaları doğuran unsurları, oturma yerine verilen önem, yer kazanmak, manzarayı veya sokağ1 seyretmek, 1şık ve serinlemek, mimari sebepler gibi beş ana başlık altında toplamıştır (Evren, 1957, 6-7). Türk Evi'nin inşasından kullanımına dek her aşamasında önemsenen ve belirleyici etkenlerden olan kadın, çıkmanın mimarlık tarihimize girmesinde temel etken olmuş olabilir. Zira, Doğan Kuban (Kuban, 2017, 14-102) konu hakkında kadının sokağı görme isteğinin zorlayıcı olduğunu ve XVII. yy.da genelleşen çıkmanın (cumbanın) bu işlevi yerine getirdiğini belirtmiştir (Kuban, 2017, 14). Daha sonra çıkma, eski düzenin anısıyla birlikte yer kazanma amacıyla yapılmaya devam edilmiştir (Kuban, 2017, 102).

Türk Evi'nde çıkma konumlandırılış ve kullanım özelliklerine göre çeşitlilik göstermektedir. Çıkma, bulunduğu mekâna göre oda çıkması, sofa çıkması 
şeklinde isimlendirilebilir (Çetin, 2006: 19-21). Taşınma biçimlerine göre ele alındığında payandalı, bindirmeli, konsol, konsol kirişli, muhtelif ve kolonlu çıkmalar olarak sınıflandırılır (Evren, 1957, 7-12). Bir başka çalışmada çeşitli çıkma uygulamalarından bahsedilmiştir. Bu uygulamalar; iki köşe çıkmalı tip, tek ve köşe çıkmalı tip, düz, kat çıkıntılı tip ve gönyeli çıkma tipleridir (Çal, 1988, 33).

Konu ile ilgili olarak tarihi vesikalara bakıldığında 1864 tarihli Vilayet Nizamnamesi'nde yeni yapılacak binaların cumba, balkon gibi sokağa bakan çıkmalarının boyut ve yüksekliklerinin sokağa göre düzenlenmesi hususunda maddelere rastlanmaktadır (Erdal, 2016: 13). Ayrıca evlerin yaşam sürelerinin uzatılması ve yangın riskinin azaltılması için ahşap yerine taş, kerpiç vb. malzeme kullanılması da dikkat çekici hususlardandır (Erdal, 2016: 13).

\section{Bafra Köy Evlerinde Çıkma}

Bafra kırsalında 9 köyde yapılan inceleme neticesinde 8 köyde 33 adet çıkmalı ev tespit edilmiştir. Malzeme yönünden de çeşitlilik arz eden bu çıkmalar konum, strüktür vb. yönlerden incelenmiştir. Bu çalışma kapsamında Bafra köy evlerinde tespit edilen üç çeşit çıkma incelenecektir. Bunlardan ilki cumba olarak da isimlendirilen ve çalışma alanındaki örneklerde sofadan çıkma yapan türdür. Genellikle kentsel mimaride görmeye alışık olduğumuz cumbalara Bafra kırsalında sıkça rastlanmaktadır. Bafra köy evleri cumbaları, uygun arazi şartları göz önüne alındığında yer kazanma amacı ön planda olmadığına göre estetik amaçla meydana getirilmiş ve bu yönü ile diğer bölge köy evlerinden ayrılmıştır. Bu durum aynı zamanda adeta genel bir kanı halini almış olan köy evlerinde işlevin estetik arayışın önüne geçtiği düşüncesinin Bafra bölgesi için -en azından bu hususta- çokta karşılık bulmadığının bir göstergesidir.

Çalışma kapsamında incelenecek bir diğer çıkma türü de kat çıkmasıdır. Kat çıkması çok sık rastlanmamakla birlikte Bafra kırsalında görülen çıkma türlerinden birisidir. Kat çıkmasının çoğunlukla asimetrik zemin kat planının düzeltilmesi amaçlı meydana getirildiği bilinmektedir. Özellikle köylerde uygun 
arazi şartları göz önüne alındığında böyle bir kullanıma gidilmesine gerek kalmamış, üst katlar düzgün zemin kat planı üzerinde yükselmiştir. Islak mekân çıkmaları Bafra kırsalında sıcça rastlanılan bir çıkma türüdür. Özellikle ahşap yapılarda tuvalet ve banyo evin bir köşesinde boydan boya ve çıkmalı olarak yapılmıştır. Bu durum islak mekânların evden koparılmak istendiği izlenimi uyandirmaktadır.

Üçüncü çıkma türü ıslak mekân çıkmasıdır. Bafra köy evlerinde tuvalet ve banyolar genellikle evin arka kısmında uzunlamasına inşa edilmişlerdir. Bu ıslak mekânlar evin arka duvarının dışına taşırılmış ve konutla bağlantısı koparılmıştır. Bu tür, ıslak mekân çıkması adı altında incelenecektir. Bu kapsamda tespit edilen çıkma türleri bulunduğu köyler de belirtilerek, incelenen ev örnekleri üzerinden açıklanacaktır.

\subsection{Terzili Köyü}

Bafra şehir merkezine 15 kilometre uzaklıkta yer alan köy (Harita 3) ova köyleri arasında değerlendirilebilir. Köy dağınık yerleşim örneği arz eder. Köyde temel geçim kaynağı çiftçilik ve hayvancılık olup incelenen köyler arasında şehir merkezine en yakın olanıdır.

Köyde tespit edilen altı çıkmalı evden ikisi ıslak mekân, dördü sofa çıkmasıdır. Ahşaptan yapılan üç evin ocaklarının üstünde inşa tarihleri yer almaktadir.

\subsection{Sofa Çıkması}

5 numaralı evde (F.1) yapım tarihi 1947 olarak (F.2) karşımıza çıkmaktadır. Ayrıca yine ocağın üzerinde yapan ibaresiyle birlikte "Cemil" ismi kaydedilmiştir. Evin giriş cephesinin üzerinde sofadan dişarı taşmak suretiyle konumlandırılan çıkma, cepheye simetrik olarak (P. 1) yerleştirilmiştir. Çıkmanın ön yüzünde iki yan cephelerinde ise birer adet pencereye yer verilmiştir. Pencereler giyotin olarak tabir edilen pencere şeklindedir. Evin alt kat yığma üst kat ahşaptır. Çıkma, ahşap malzemedendir. 
2 numaralı ev (F.3), ocağın üstündeki bilgiden hareketle 1962 tarihlidir (F.4). Ocağın üzerinde usta ismi “Kocatürk” olarak kaydedilmiştir (F.4). Çıkma, evin giriş cephesinin üzerinde ve sofadan çıkıntı yapmak suretiyle cepheye simetrik olarak (P.2) yerleştirilmiştir. Çıkmanın her cephesinde birer tane pencereye yer verilmiştir. Ev, alt katta yığma üst katta ahşap olarak inşa edilmiş olup çıkma da ahşap malzemedendir.

4 numaralı ev (F.5), ocağın üzerindeki bilgiden hareketle 1984 yılına tarihlense de (F.6) ev sahibinden alınan bilgiyle ocağın onarım gördüğü ve bu onarım sırasında bu tarihin düşüldüğü anlaşılmıştır. Alt katta yığma olarak inşa edilen ev üst katta ahşap malzemeden yapılmıştır. Yine ahşap malzemeden yapılan çıkma, giriş cephesinin hemen üzerinde cepheyi ortalayacak şekilde simetrik olarak (P.3) yerleştirilmiştir. Ön cephede iki yan cephelerde birer pencere yer almaktadır.

1 numaralı evin (F.7) inşa tarihine ya da usta ismine dair bir kayıt yoktur. Yı̆̆ma olarak inşa edilen evin çıkması, girişin hemen üzerinde cepheye simetrik olarak yerleştirilmiş olup pencere düzeni süreklilik göstermektedir.

\subsubsection{Islak Mekân Çıkması}

3 (F.8-P.4) ve 5 (F.9- P.1) numaralı evlerde 1slak mekânlar (banyo, tuvalet) evin arka kısmında ahşap olarak inşa edilmiştir.

\subsection{Kolay Köyü}

Bafra şehir merkezine 23 km uzaklıkta yer alan köy (Harita 4) Bafra'nın eski beldelerinden olup Altınkaya Barajı'nın yakınındadır. Toplu yerleşimin görüldüğü köyde tarım ve hayvancılık temel geçim kaynağıdır. İncelemeler neticesinde köyde üç tane çıkmalı ev tespit edilmiştir.

\subsubsection{Sofa Çıkması}

1 numaralı ev (F.10- P.5), sahibinin ifadesine göre en az yüz yıllıktır. Zemin kat yığma taş, birinci kat tuğla, ikinci kat ise ahşap malzemeden inşa edilmiştir. Günümüzde hâlâ kullanılan ve oldukça bakımlı olan evin çıkması ahşap malzemeden yapılmış olup cepheye simetrik olarak yerleştirilmiştir. Çıkmanın tüm cephesi baştanbaşa pencere dizisiyle düzenlenmiştir. 
2 numaralı ev (F.11- P.6) gerek inşa malzemesi gerekse çıkma strüktürü olarak birinci evle aynı özellikleri göstermektedir. Ahşap çıkma burada da cepheye simetrik olarak yerleştirilmiştir.

3 numaralı ev (F.12- P.7) tuğla malzemeden inşa edilmiş olup evin çıkması girişin hemen üzerinde, cepheye simetrik olarak yerleştirilmiştir. Ön cephede iki, yan cephelerde birer sira pencere düzeni görülmektedir.

\subsection{Kuzalan Köyü}

Bafra'nın güneyinde yer alan köy (Harita 5) Bafra şehir merkezine 33 kilometredir. Köyde yapılan incelemede bir evde iki çıkma türüne rastlanmıştır.

\subsubsection{Sofa Çıkması}

Zemin katta yığma taştan inşa edilen 1 numaralı evin üst katında tuğla malzeme ve bağdadi yapım sistemi devreye girmiştir. Ahşap direklerle taşınan çıkma (F.13-P. 8), ön cephede iki sıra yan cephelerde ise bir taraf penceresiz olarak düzenlenmiştir.

\subsubsection{Islak Mekân Çıkması}

Aynı evin arka cephesinde (F.14-P.8) banyo ve tuvalet kısmı çıkmalı olarak düzenlenmiş olup inşa malzemesi tuğladır.

\section{5. Şahinkaya Köyü}

İncelenen köyler arasında Bafra şehir merkezine en uzak mesafedeki köy (Harita 6) dağ köyleri kapsamındadır. Şehir merkezine 60 kilometre mesafede yer alan köyün temel geçim kaynağı tütün ve hayvancılıktır. Köyde üç çıkma türünde sekiz adet ev tespit edilmiş olup bu evlerin altısı ahşap ikisi tuğla malzemeden inşa edilmiştir.

\subsubsection{Sofa Çıkması}

1 numaralı ev (F.15-P.9) zemin katta yığma taş, üst katta ahşap olarak inşa edilmiştir. Girişin hemen üzerinde cepheye simetrik olarak yerleştirilen çıkma ön cephede iki sıra, yan cephelerde ise biri sağır olarak düzenlenmiş pencerelere sahiptir. 
2 numaralı ev (F.16-P.10) tümüyle ahşap malzemedendir. Yine cepheye simetrik yerleştiril çıkma, ön cephede ve yanlarda birer sıra pencere düzeni gösterir.

3 numaralı ev (F.17-P.11) zemin katta yığma taş, üst katta ise ahşap olarak inşa edilmiştir. Çıkma evin girişinin hemen üzerinde yer almakta olup üç yönde birer pencere ile dışarıya açılmıştır. Evin pencereleri giyotin pencere olarak düzenlenmiştir.

\subsubsection{Kat Çıkması}

4 (F.18-P.12) ve 5 (F.19-P.13) numaralı evler genellikle köy evlerinde karşımıza çıkmayan kat çıkmalı olarak inşa edilmiştir. Böylece alt kattaki düzensizlik üst katta çıkma vasıtası ile düzelmiş ve düzgün bir plan elde edilmiştir.

\subsubsection{Islak Mekân Çıkması}

Köyde dört adet çıkma ile karşılaşılmıştır. Bu evlerden 6 ve 7 numaralı evler ahşap (F. 20-P.14, F.21-P.15), 8 ve 9 numaralı evler tuğla malzemeden (F.22P.12, 23-P.13) yapılmıştır. Islak mekânlar bu evlerde de giriş aksının karşısına evin arka cephesinden taşıntı yapacak şekilde inşa edilmiştir.

\subsection{Bengü Köyü}

Bafra ilçesinin dă̆ köylerinden sayılan Bengü köyü (Harita 7) ilçe merkezine yaklaşık 40 km'dir. Köyün temel geçim kaynağı hayvancılık olup kışları çok sert geçmektedir. Köyde 3 adet çıkmalı eve rastlanmış olup bunlardan 1 ve 2 numaralı olan ev tuğla (F.25-26) 3 numaralı ev ahşap (F.24) ancak çıkması tuğladandır. Köyde ıslak mekân haricinde bir çıkma türüne rastlanmamıştır.

\subsubsection{Islak Mekân Çıkması}

1 (P.16) ve 2 (P.17) numaralı evlerde bu çıkmalar evin giriş aksının karşısına, 3 numaralı (P.18) evde ise eve giriş aksının sağında inşa edilmiştir. 3 numaralı evin ıslak mekân çıkmasının sonradan eklendiği malzeme yönünden kendisini ele vermektedir. 


\section{7. Çulhakoca Köyü}

Bafra şehir merkezine yaklaşık $30 \mathrm{~km}$ mesafede yer alan köy (Harita 8) dağ köyleri arasında yer almaktadır. Köyde yapılan incelemede dört adet çıkmalı eve rastlanmıştır. Köyde ıslak mekân çıkması haricinde bir çıkma türüne rastlanmamıştır.

\subsubsection{Islak Mekân Çıkması}

Tespit edilen evlerden 1 (P.19) ve 3 (P.21) numaralı evler (F.27-29) ahşap 2 (P.20) ve 4 (P.22) numaralı evler (F.20-30) tuğla malzemeden inşa edilmiştir. Bunlardan 1,2 ve 4 numaralı evlerin çıkmaları eve girişin karşı kısmında, evin arka yönüne inşa edilmişken 3 numaralı evin çıkması giriş aksının sol tarafında düzenlenmiştir.

\subsection{Karakütük Köyü}

Bafra şehir merkezine $45 \mathrm{~km}$ uzaklıkta yer alan yerleşimde (Harita 9) insanların temel geçim kaynağı hayvancılıktır. Köyde yapılan incelemede sadece bir tane (F.31) 1slak mekân çıkmalı eve (P.23) rastlanmıştır. Ahşap malzemeden inşa edilen bu evin çıkması girişin sağındadır.

\subsection{Meşelitürkmenler Köyü}

Meşelitürkmenler Köyü Bafra şehir merkezine uzak köylerdendir. Bafra'ya yaklaşı $50 \mathrm{~km}$ mesafede yer alan köyde (Harita 10) temel geçim kaynağı hayvancılık ve tütün üretimidir. Köyde üç tane çıkmalı ev tespit edilmiştir. $\mathrm{Bu}$ evlerin hepsi ahşap malzemedendir.

\subsubsection{Islak Mekân Çıkması}

1 numaralı evde (F.32-P.24) girişin karşısına evin arkasına yerleştirilen 1slak mekân 3 (P.25) ve 4 (P.26) numaralı evlerde (F.34-35) eve girişin sağında düzenlemiştir.

\subsubsection{Kat Çıkması}

2 numaralı evin (F.33) çıkması girişin sağında konumlandırılmış olup bu çıkma hem ıslak mekânı hem de odayı taşımaktadır. 


\section{Değerlendirme ve Karşılaştırma}

Çalı̧̧ma kapsamında dokuz köy incelenmiştir. Bu köylerden; Şahinkaya, Bengü, Meşelitürkmenler, Çulhakoca Karakütük köylerini dağ köyleri olarak nitelendirebiliriz. Terzili, Kolay, Kuzalan, Kapıkaya köyleri ise şehir merkezine daha yakın ova köyleri kapsamında değerlendirilebilir. Dokuz köyün tümünde geleneksel yöntemle yapılmış yaklaşık atmış ev tespit edilmiş olup bunların on bir tanesi çıkmalıdır.

Çıkmalar Türk konut geleneğinde kentsel mimaride olduğu kadar kırsal mimaride de kendisine uygulama alanı bulmuştur. Bu çıkma kullanımı doğal olarak çeşitli bölgelerde yerel üslup, yaptıran isteği vb. nedenlerle çeşitli biçimlerde şekillenmiştir. Bafra kırsalındaki çıkma türleri kendi arasında gruplanacak olursa üç çeşit tür ile karşılaşılmaktadır. Bunlardan birincisi sofa çıkması ya da cumba olarak da bilinen çıkma türü olup Anadolu'nun gerek kırsal gerek kentsel mimarisinde sıkça karşımıza çıkan bir kullanımdır. Burdur ili Dirmil kırsalı (Kocaman, 2017:84), Kastamonu ili Hanönü kırsalı (Güler, Keçici, Saluk, Atala, 2017: 99), Rize ili Çamlıhemşin kırsalı (Ufuk, 2017: 117) sofa çıkmaları Bafra kırsalı ile aynı tarzın farklı yerlerdeki kullanımıdır.

Islak mekân çıkmaları Bafra köy evlerinin değişmez unsurlarındandır. Genellikle evlerin giriş yönünün karşısında ve arka cephede konumlandırılan bu çıkmalar cephede boydan boya uzanmaktadır. Alttan genelde eliböğründe vasıtasıyla desteklenen çıkmalar tuvaleti adeta evden kopartan bir görünüme sahiptir. Bu durum, dışarıda yer alan tuvaletin ev içine alınışının kademeli süreci gibidir. Bu kullanıma Karadeniz bölgesi köy evlerinin çoğunda ve bölgenin tüm illerinde rastlanılır.

Kat çıkması genel anlamda uygun olmayan arazi şartlarında yapılan evlerin üst kat planının düzeltilmesi amaçlıdır. Bafra kırsal mimarlığı özelinde ve Anadolu kırsal mimarlığı genelinde düşünüldüğünde -topoğrafyanın el verdiği bölgelerdeköy evlerinin geniş ve uygun arazi şartlarına yerleştirilmesi kat çıkmasının kendisine çok kullanım alanı bulamamasına neden olmuştur. Bu nedenle olsa gerek ki 
Bafra kırsalında şimdiye kadar tespit edilen kat çıkmaları bir elin parmaklarını geçmemektedir.

Anadolu konut mimarlığında rastlanılan bazı çıkma tipleri vardır ki Bafra kırsalında uygulama alanı bulmamıştır. Örneğin üst katın iki köşesinde birer çıkma yapan plan tipi hem Tokat kent mimarlı̆̆ında (Çal, 1988: 25) hem de Kocaeli ili Gölcük ilçesi Saraylı Köyü’nde (Usanmaz, Eyüpgiller, 2007: 17) karşımıza çıkarken Bafra'da henüz örneğine rastlanmamıştır. Yada yapının bir köşesinden başlayıp cephenin bir bölümüne kadar devam eden çıkma tipine Bursa'nın Deliballar Köyü'nde rastlanırken (Güneş, Eyüpgiller: 32) Bafra kırsalında henüz rastlanmamıştır.

Tek köşe çıkmalı, gönyeli çıkma, yuvarlak dilimli cephe gibi cephe tipleri ise Bafra kırsal mimarlığında şuana dek karşımıza çıkmayan tiplerdendir.

\section{Sonuç}

Araştırmamız neticesinde sekiz köyden otuz iki çıkmalı ev malzeme, konum, strüktür vb. açıdan incelenmiştir. Daha çok kent mimarlığında görmeye alıştı̆̆ımız çıkmaların köy evlerinde karşımıza çıkması dikkat çekici bir husustur. Manzara, mahremiyet vb. unsurların çıkma mimarisinin temelinde yatan hususlar olduğu bilinmektedir. Köy evlerinin zaten manzaraya yöneldiği ve dağınık yerleşim olmasa dahi evlerin birbirinden mesafeli konumlandırılması gibi durumlar göz önüne alındığında çıkmaların şehir mimarlığındaki mimari beğeni ve zevklerin köy mimarlı̆̆ına yansımaları olduğu sonucuna varılır.

Bafra köy evlerinde çıkmalar, girişin sağlandığı cepheye ve giriş kapısının hemen üzerine inşa edilmiş ve ahşap direk ya da eliböğründe ile desteklenmiştir. $\mathrm{Bu}$ haliyle bir sundurma vazifesi de görmüş olan çıkmalar, köy evlerini monoton ve durağan görünümden kurtarmış, ona barınma amacının ötesinde mimari anlamlar yüklendiğini de göstermiştir. Bafra köy evleri çıkmaları sofadan taşıntı yapmaktadır. Cepheye simetrik olarak konumlanmaları da bu nedenledir. Bafra köy evlerindeki çıkmaların amacı üst kata düzgün bir plân özelliği kazandırmak değild- 
ir. Köy yapılarında inşa alanı sıkıntısı olmadığı için evlerin plânları genel anlamda düzgün arazi şartlarında meydana getirilir. Bu yüzdende üst katta çıkma vasıtasıyla düzgün bir plân özelliği arayışına ihtiyaç kalmamaktadır. Bu nedenle Bafra köy evlerindeki mevcut çıkmalar zorunluluk değil, ancak beğeni ve yaptıranın isteği ile açıklanabilecek mimari kullanımlardır. Fakat Anadolu'nun köy evlerinde farklı çıkma türleri, topoğrafyaya, zemin özelliklerine ve manzaraya göre çeşitlilik de gösterebilmektedir.

Bafra'nın çıkmalı köy evlerinde rastlanan usta imzaları gerek kırsal mimarlık gerekse mimarlık tarihi açısından ayrı bir önem arz eder. Anıtsal mimaride görmeye alıştığımız usta ve sanatkâr imzalarına (Sönmez, 1989:49-463; Bayburtluoğlu, 1993: 20-80; Tümer, 2012: 163) Anadolu'nun ücra köylerinde de rastlanması yapı ustasının adını unutturmak istememesi ve inşa ettiği evdeki manevi varlı̆̆ıdır. Anadolu kırsalında rastlanan bu yapı ustası imzası geleneğinin (Kocaman, 2017: 86) Bafra kırsal konutlarında da devam ettiği sonucuna varılmıştır.

\section{Kaynakça}

Akın, N. (1995). Ev. Diyanet İslam Ansiklopedisi. 11. 507-512.

Aslanapa, O. (2004). Osmanlı devri mimarisi. İstanbul: Anka Basım.

Başkan, S. (2008). Geleneksel karadeniz evleri. Atatürk Dil ve Tarih Yüksek Kurumu. 52. 41-90.

Bayburtluoğlu, Z. (1993). Anadolu'da Selçuklu dönemi yapı sanatçıları. Erzurum: Atatürk Üniversitesi Yayınları.

Bozkurt, N. (1995). Ev. Diyanet İslam Ansiklopedisi. 11. 502-507.

Cansever, T. (2002). Türk evi'nin mimarisi. Türkler Ansiklopedisi. 12. 313-320.

Çal, H. (1988). Tokat evleri. Ankara: Kültür ve Turizm Bakanlığı Yayınları.

Çetin, Y. (2006). Geleneksel Türk evinde cumba. Sanat Tarihi Dergisi. 15. (2), 17-27.

Eldem, S. (1984). Türk evi. İstanbul: Taç Vakfi.

Erdal, Z. (2016). Aksaray evleri. (1. Basım). Ankara: Demirok Matbaacilık.

Erler, F. (2009). Osmanlı nüfus kayıtlarına dair alternatif bir kaynak: defter-i liva-1 canik 1837. Uluslararası Sosyal Araştırmalar Dergisi. 2/8. 169-190. 
Güler, K., Keçici, Z., Saluk, Y., Atala, Ö., Z., (2017). Kırsal yerleşmelerde ticari alanlar: Kastamonu - Hanönü örneği. K.K. Eyüpgiller- Z. Eres- A. C. Bilge ve M. A. Çinko. (Editörler). Kırsal Mimarlık Mirasının Korunması Türkiye’den ve Dünyadan Örnekler. İstanbul: Arkeoloji ve Sanat Yayınları.

Güneş, S., Eyüpgiller K., (2017). Bursa deliballar köyü sit koruma projesi. K.K. EyüpgillerZ. Eres- A. C. Bilge ve M. A. Çinko. (Editörler). Kırsal Mimarlık Mirasının Korunması Türkiye'den ve Dünyadan Örnekler. İstanbul: Arkeoloji ve Sanat Yay.

Kocaman, N. (2017). Dirmil / Altınyayla kırsal dokusu ve geleneksel konutları. K.K. Eyüpgiller- Z. Eres- A. C. Bilge ve M. A. Çinko. (Editörler). Kırsal Mimarlık Mirasının Korunması Türkiye'den ve Dünyadan Örnekler. İstanbul: Arkeoloji ve Sanat Yayınları.

Kuban, D. (2017). Türk ahşap konut mimarisi 17-19. yüzyıllar. İstanbul: Türkiye İş Bankası Kültür Yayınları.

Küçük, M. (2018). Bafra ilçesinin coğrafyası. Yayımlanmamış yüksek lisans tezi, Karabük: Karabük Üniversitesi Sosyal Bilimler Enstitüsü.

Özçelebi, M. A. (2015). Bafra ve Kavak organize sanayi bölgelerinin karşılaştırmalı coğrafi analizi. Yayımlanmamış yüksek lisans tezi, Samsun: 19 Mayıs Üniversitesi Sosyal Bilimler Enstitüsü.

Özgüner, O. (1970). Köyde mimari doğu karadeniz. Ankara: Dergah Yayınları.

Sönmez, Z. (1995). Anadolu Türk-İslam mimarisinde sanatçılar. İstanbul: Türk Tarih Kur.

Sözen, M., Tanyeli, U., (2003). Sanat kavram ve terimleri sözlüğü. İstanbul: Remzi Kitabevi.

Özkan, T. (2012). 19. yüzyılın ilk yarısında Bafra kazası nüfusu. Yayımlanmamış yüksek lisans tezi. Samsun: 19 Mayıs Üniversitesi Sosyal Bilimler Enstitüsü.

Tuna, C. (2009); İkiztepe yapıları, İstanbul, Arkeoloji ve Sanat Yayınları.

Tümer, Ş. (2012). Mimar Dâvud Ăga'nın hayatı, eserleri ve üslup anlayışı. Yayımlanmamış yüksek lisans tezi. Van: Yüzüncü Yıl Üniversitesi Sosyal Bilimler Enstitüsü.

Ufuk, R., S., (2017). Çamlıhemşin'deki tarihi konakların turizm potansiyeli. K.K. Eyüpgiller- Z. Eres- A. C. Bilge ve M. A. Çinko. (Editörler). Kırsal Mimarlık Mirasının Korunması Türkiye'den ve Dünyadan Örnekler. İstanbul: Arkeoloji ve Sanat Yayınları.

Usanmaz, B., Eyüpgiller, K. (2017). Saraylı köyü: kentsel doku, mimari ve koruma. K.K. Eyüpgiller- Z. Eres- A. C. Bilge ve M. A. Çinko. (Editörler). Kırsal Mimarlık Mirasının Korunması Türkiye'den ve Dünyadan Örnekler. İstanbul: Arkeoloji ve Sanat Yayınları. 


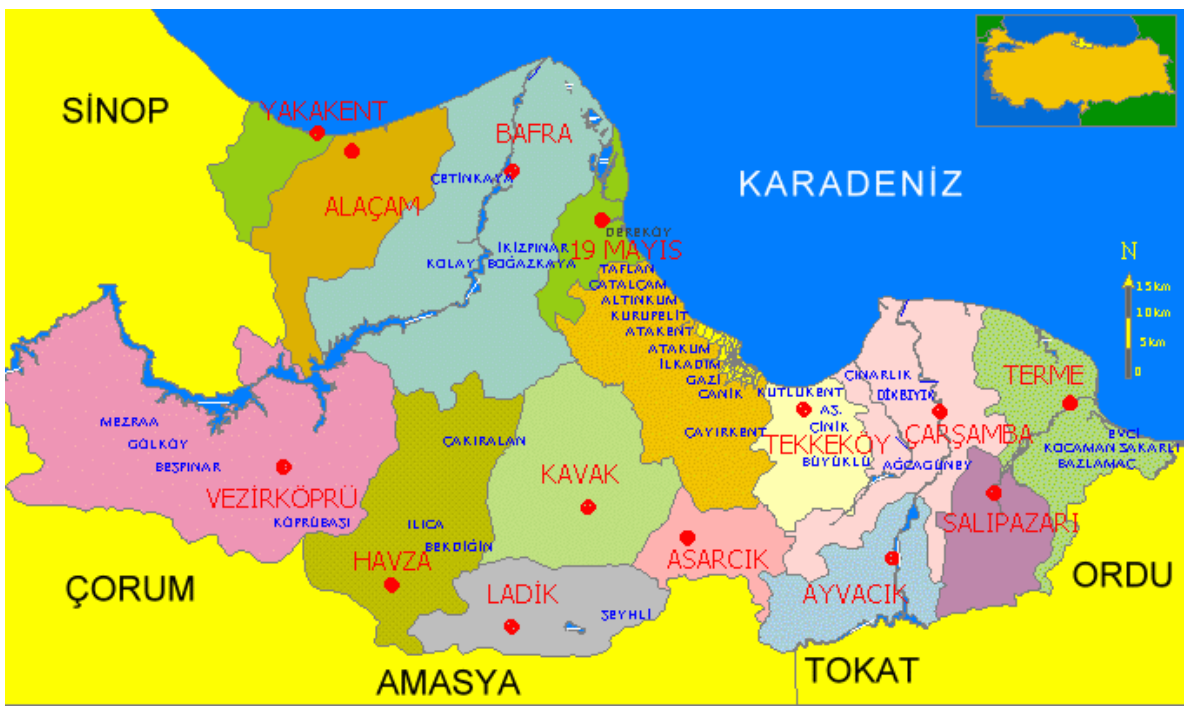

H.1. Bafra Siyasi Haritası (http://www.samsunbulten.com)

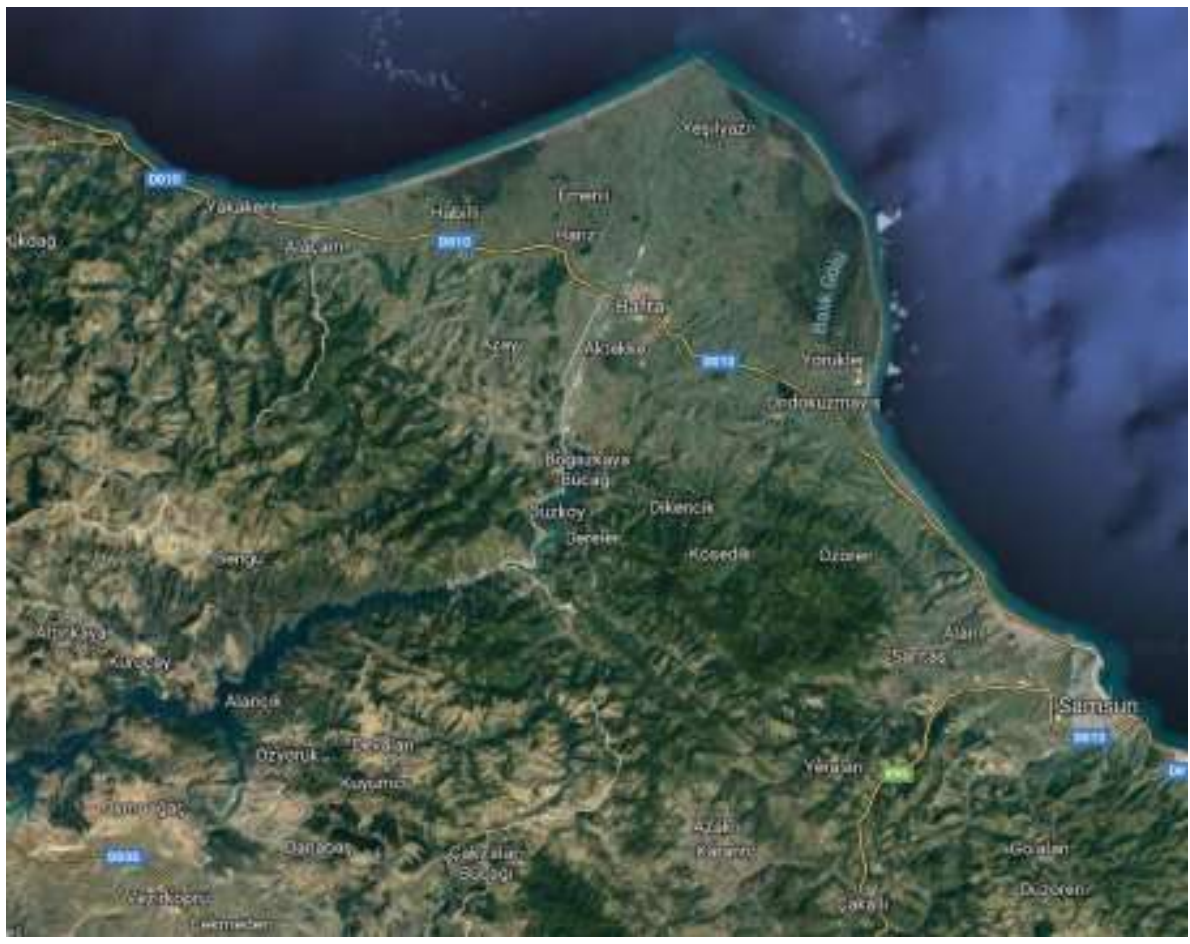

H.2. Bafra’nın Fiziki Görünümü (maps.google.com) 


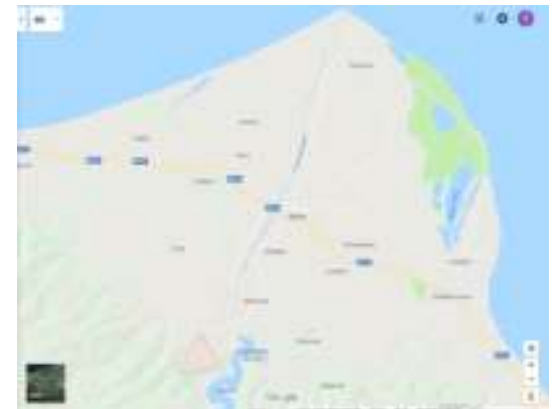

H. .3. Terzili Köyü (maps.google.com)

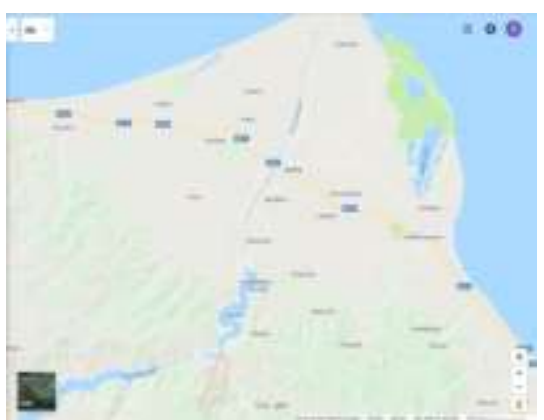

H.5. Kuzalan Köyü (maps.google.com)

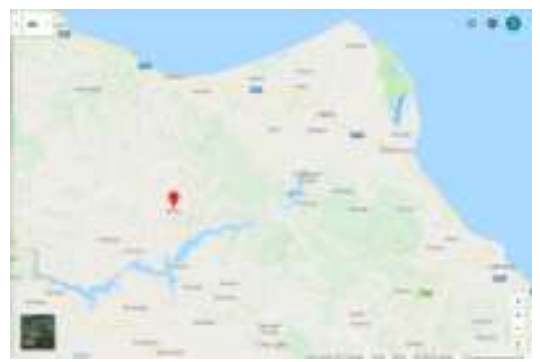

H.7. Bengü Köyü (maps.google.com)

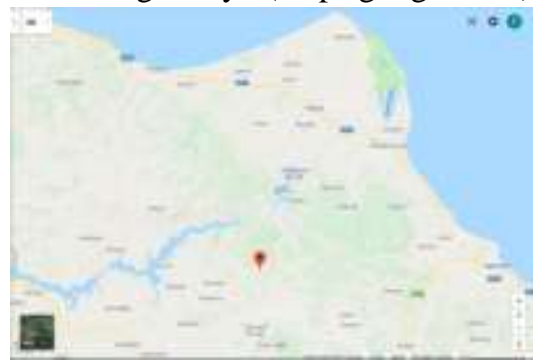

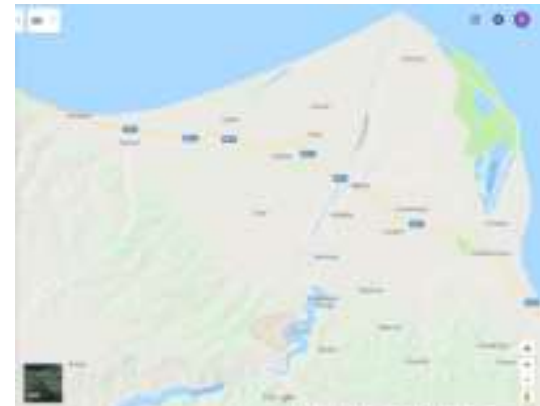

H.4. Kolay Köyü (maps.google.com)

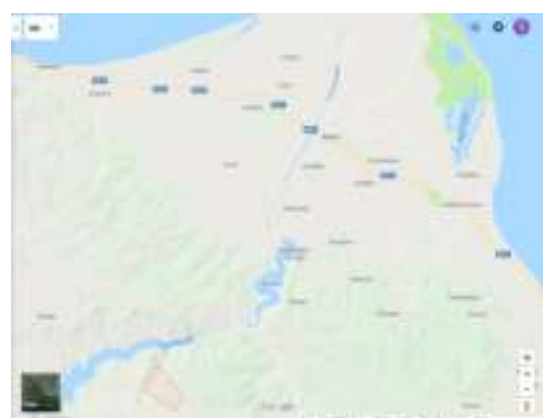

H.6. Şahinkaya Köyü (maps.google.com)

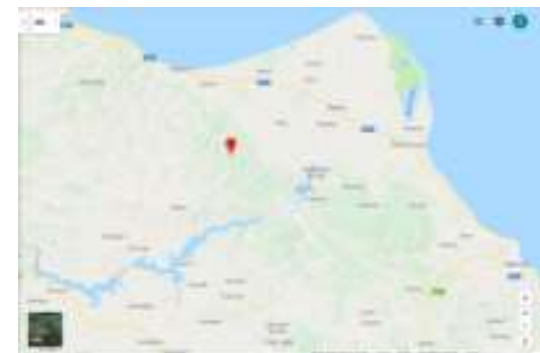

H.8. Çulhakoca Köyü (maps.google.com)

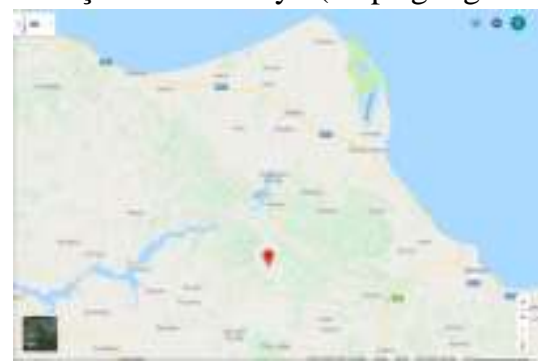

H.9. Karakütük Köyü (maps.google.com)H.10. M.türkmenler Köyü (maps.google.com) 

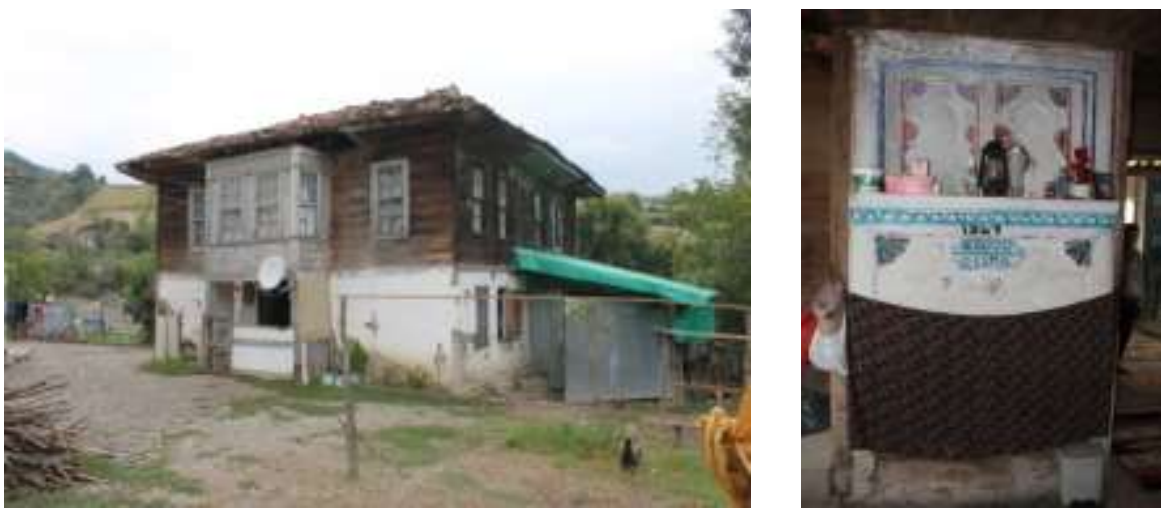

F.1. Terzili Köyü 5 Nolu Ev

F.2. Terzili Köyü 1 Nolu Ev
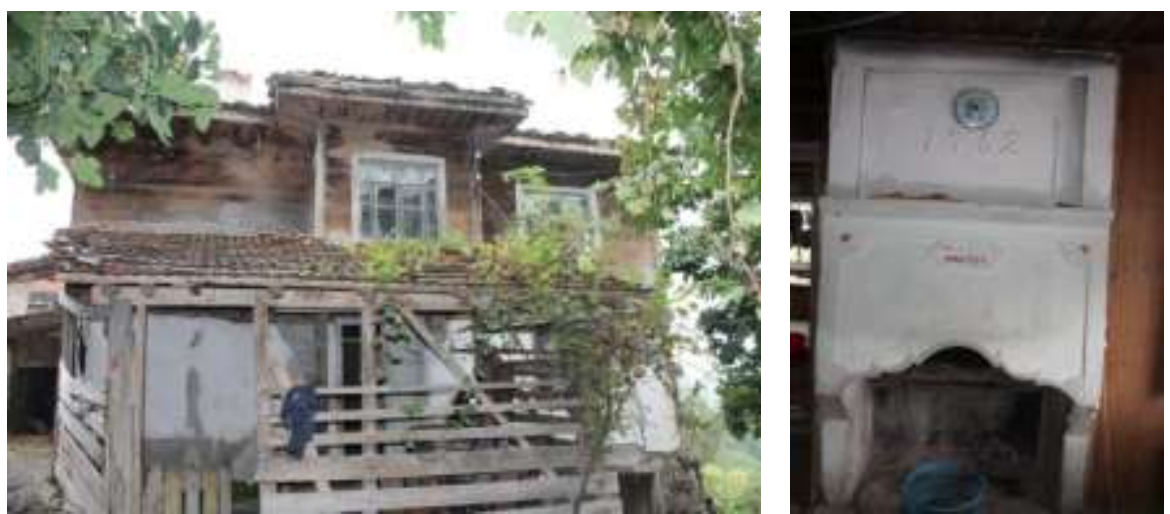

F.3. Terzili Köyü 2 Nolu Ev

F.4. Terzili Köyü 2 Nolu Ev
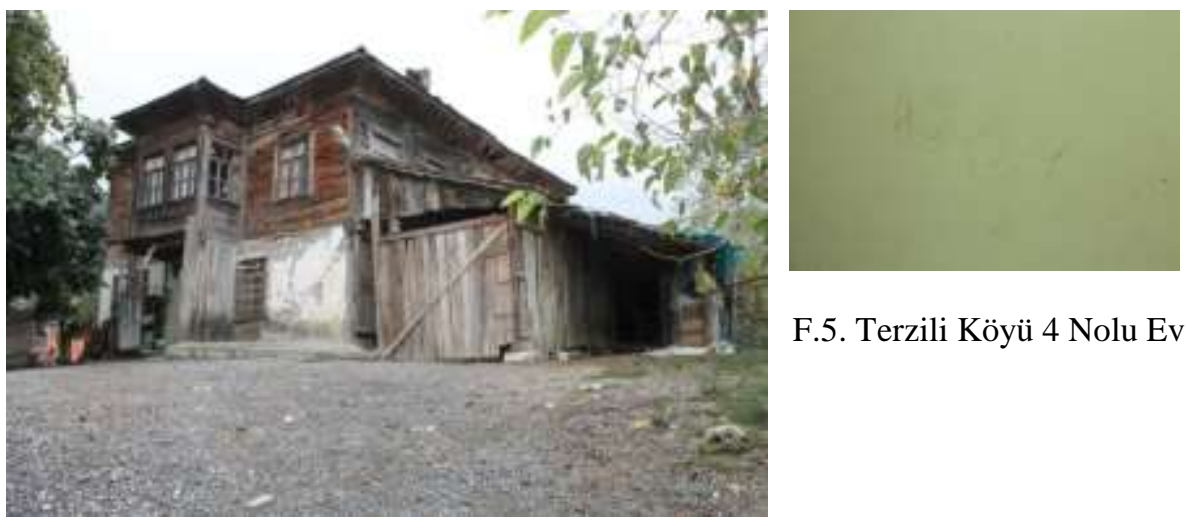

F.5. Terzili Köyü 4 Nolu Ev

F.6. Terzili Köyü 4 Nolu Ev 


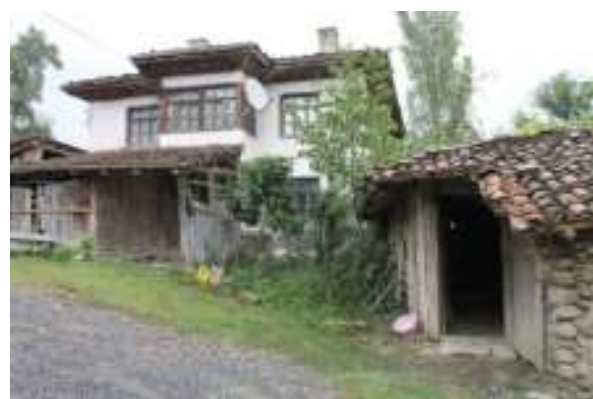

F.7.Terzili Köyü 1 Nolu Ev

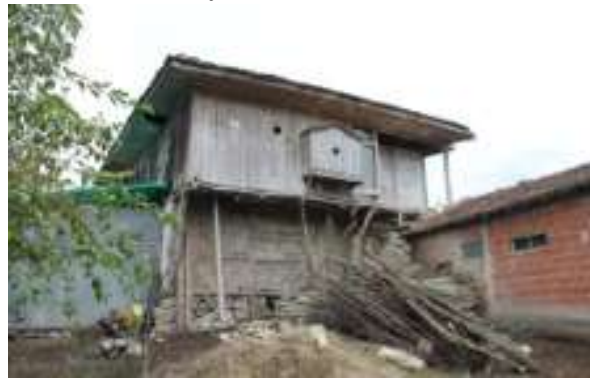

F.9. Terzili Köyü 5 Nolu Ev

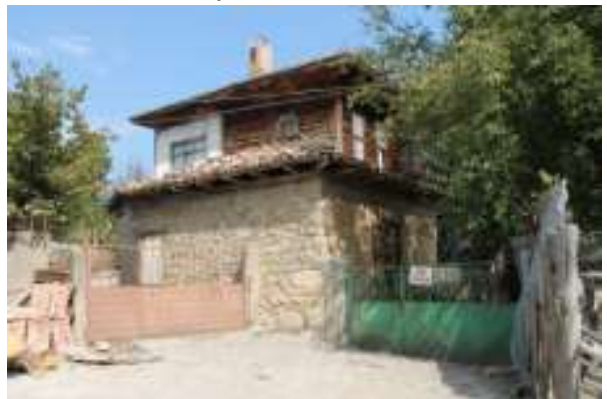

F.11. Kolay Köyü 2 Nolu Ev

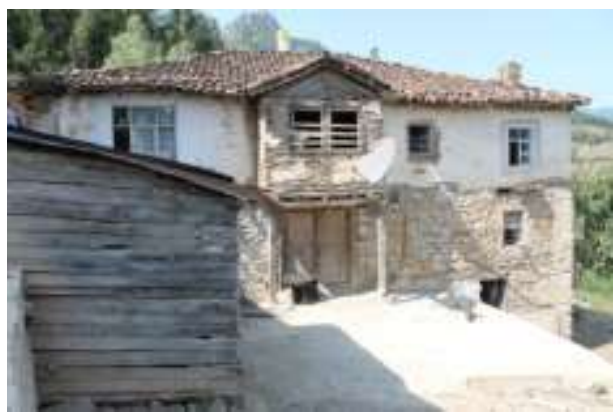

F.13. Kuzalan Köyü 1 Nolu Ev

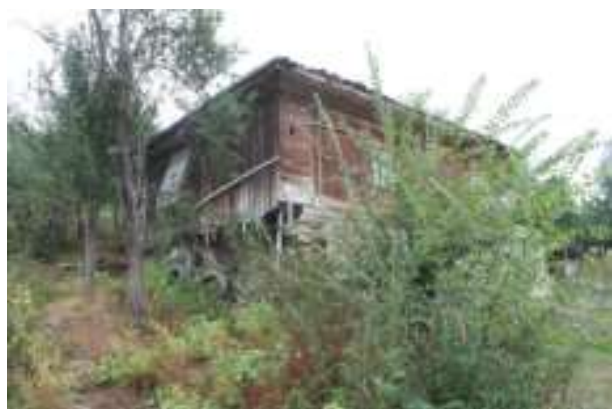

F.8. Terzili Köyü 3 Nolu Ev

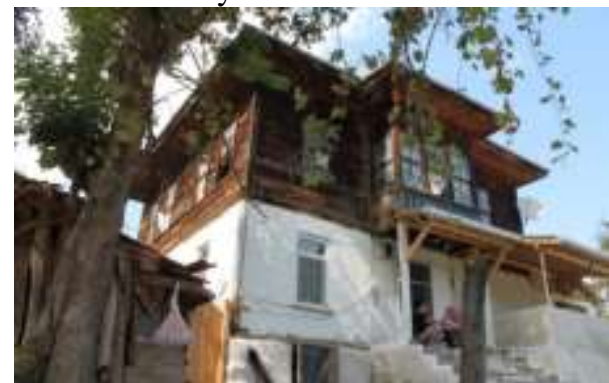

F.10. Kolay Köyü 1 Nolu Ev

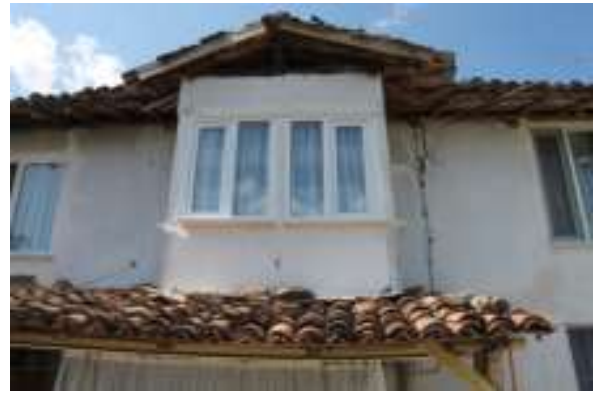

F.12. Kolay Köyü 3 Nolu Ev

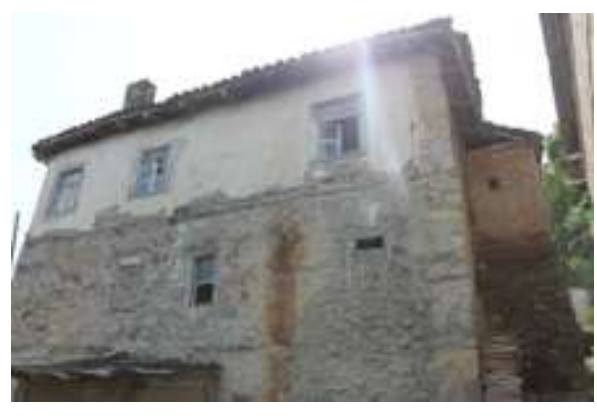

F.14. Kuzalan Köyü 1 Nolu Ev 


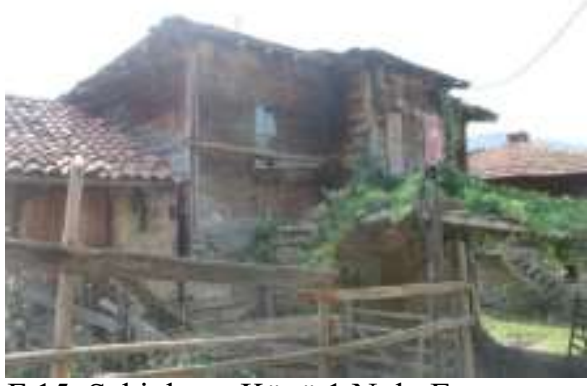

F.15. Şahinkaya Köyü 1 Nolu Ev

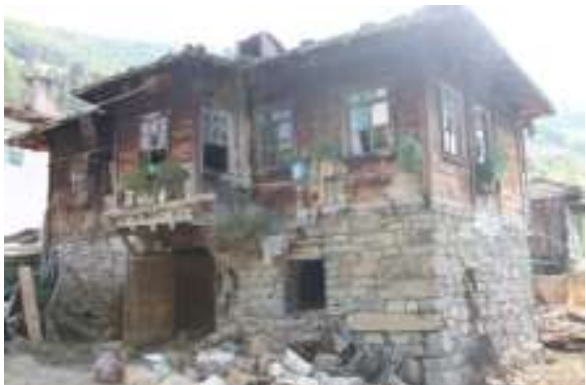

F.17. Şahinkaya Köyü 3 Nolu Ev

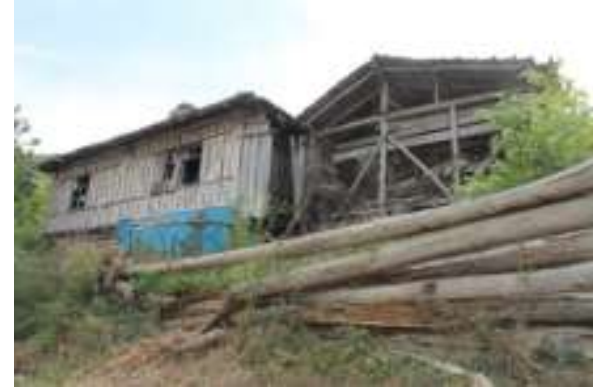

F.19. Şahinkaya Köyü 5 Nolu Ev

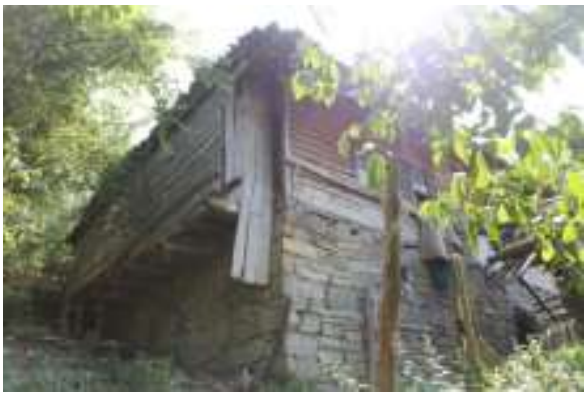

F.21. Şahinkaya Köyü 7 Nolu Ev

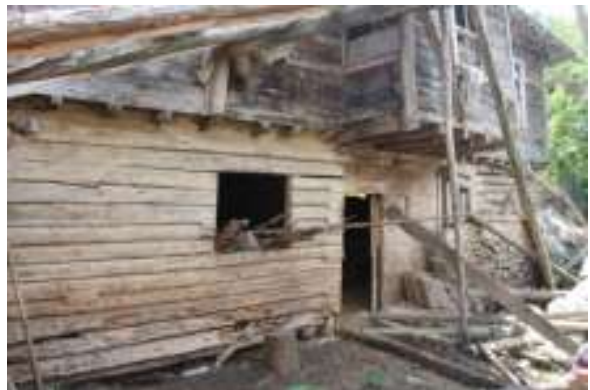

F.16. Şahinkaya Köyü 2 Nolu Ev

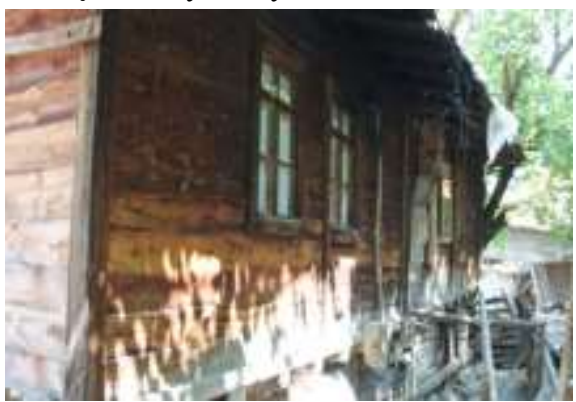

F.18. Şahinkaya Köyü 4 Nolu Ev

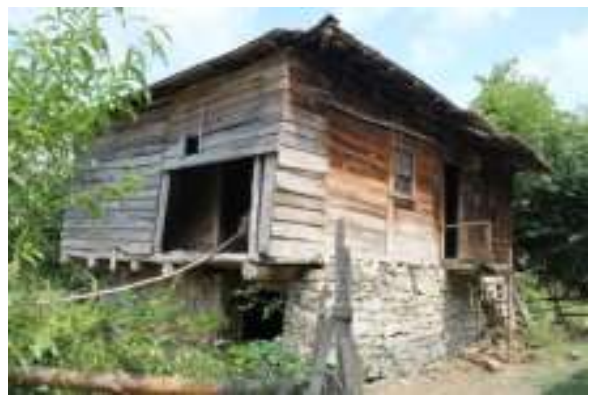

F.20. Şahinkaya Köyü 6 Nolu Ev

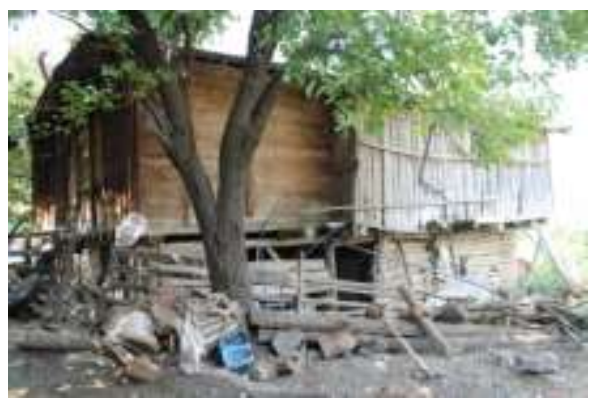

F.22. Şahinkaya Köyü 8 Nolu Ev 


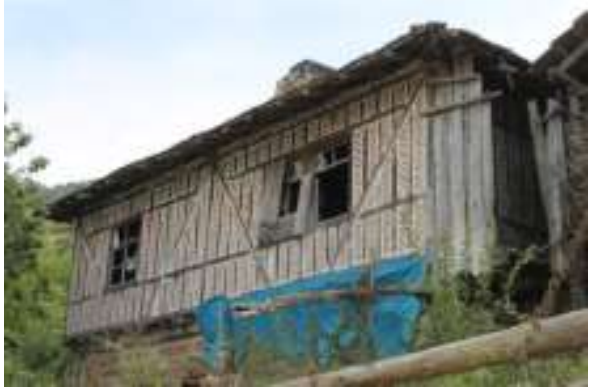

F.23.Şahinkaya Köyü 9 Nolu Ev

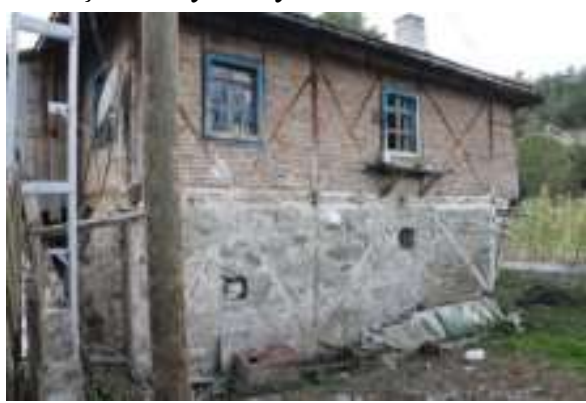

F.25. Bengü Köyü 2 Nolu Ev

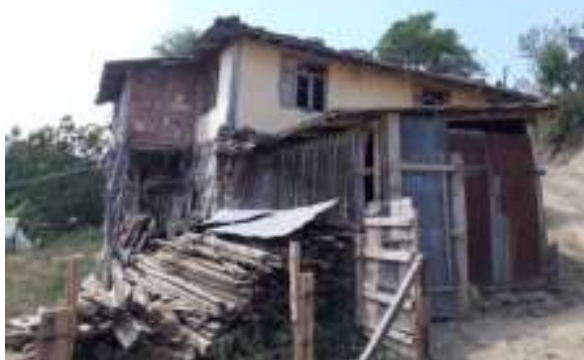

F.27. Çulhakoca Köyü 1 Nolu Ev

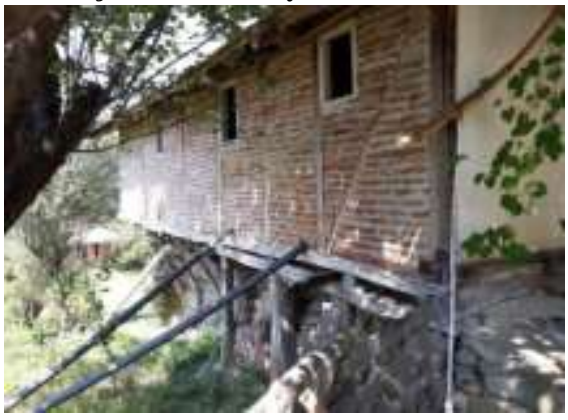

F.29.Çulhakoca Köyü 3 Nolu Ev

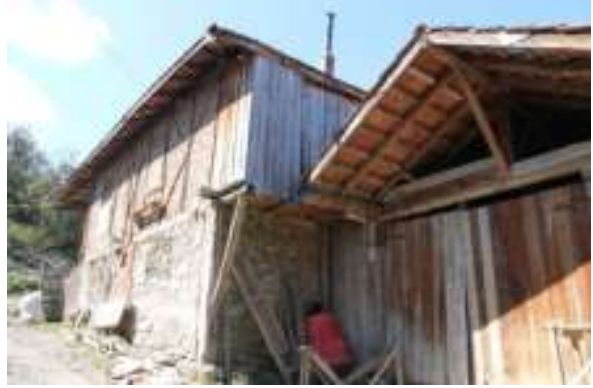

F.24. Bengü Köyü 1 Nolu Ev

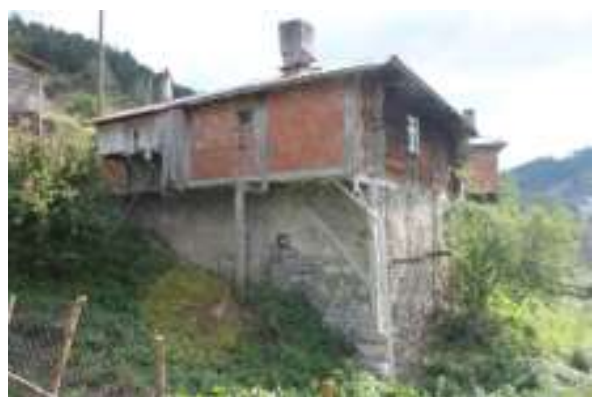

F.26. Bengü Köyü 3 Nolu Ev

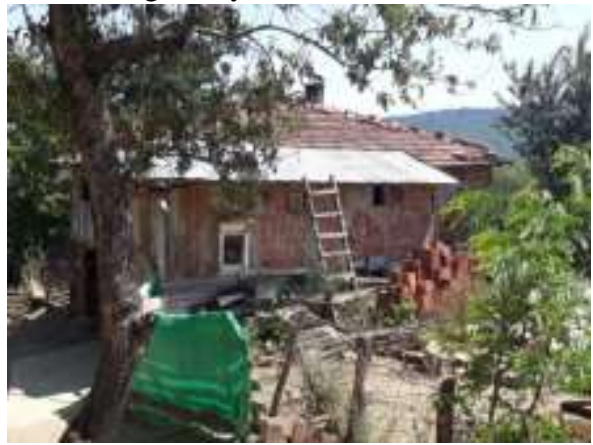

F.28. Çulhakoca Köyü 2 Nolu Ev

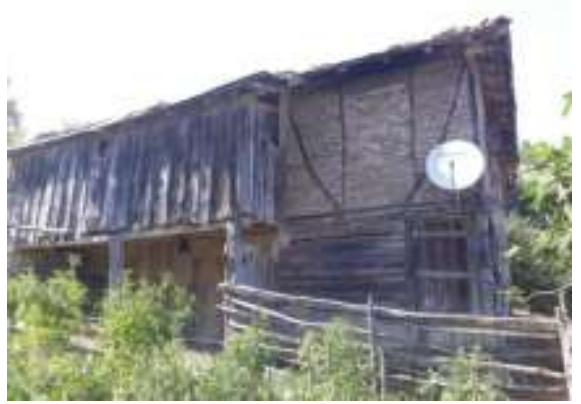

F.30. Çulhakoca Köyü 4 Nolu Ev 


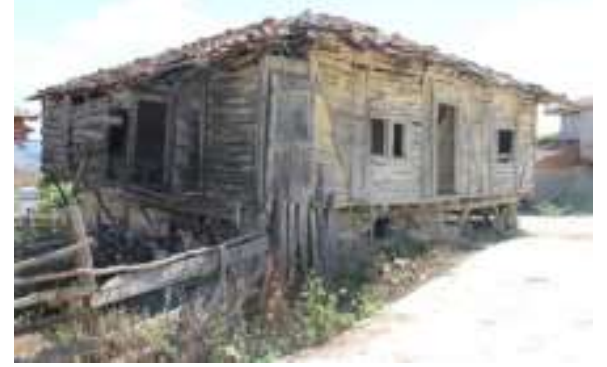

F.31.Karakütük Köyü 1 Nolu Ev

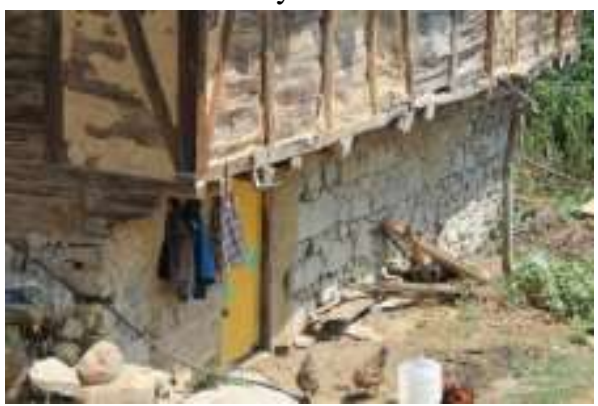

F.33.Meşelitürkmenler Köyü 2 Nolu Ev

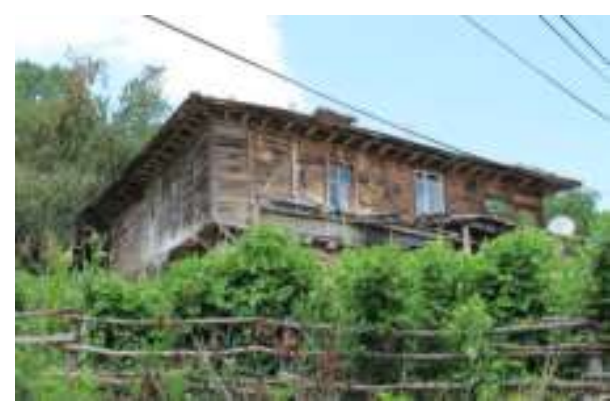

F.32. Meşelitürkmenler Köyü 1 Nolu Ev

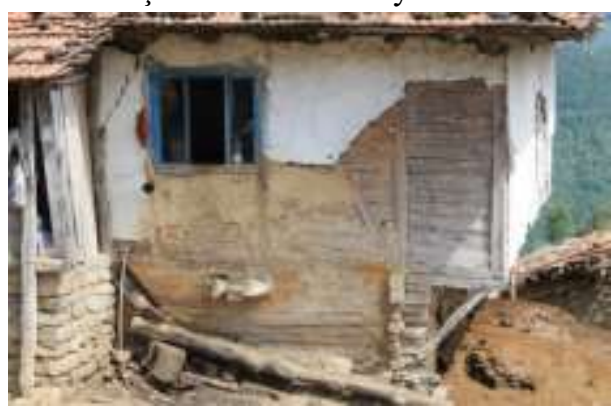

F.34. Meşelitürkmenler Köyü 3 Nolu Ev

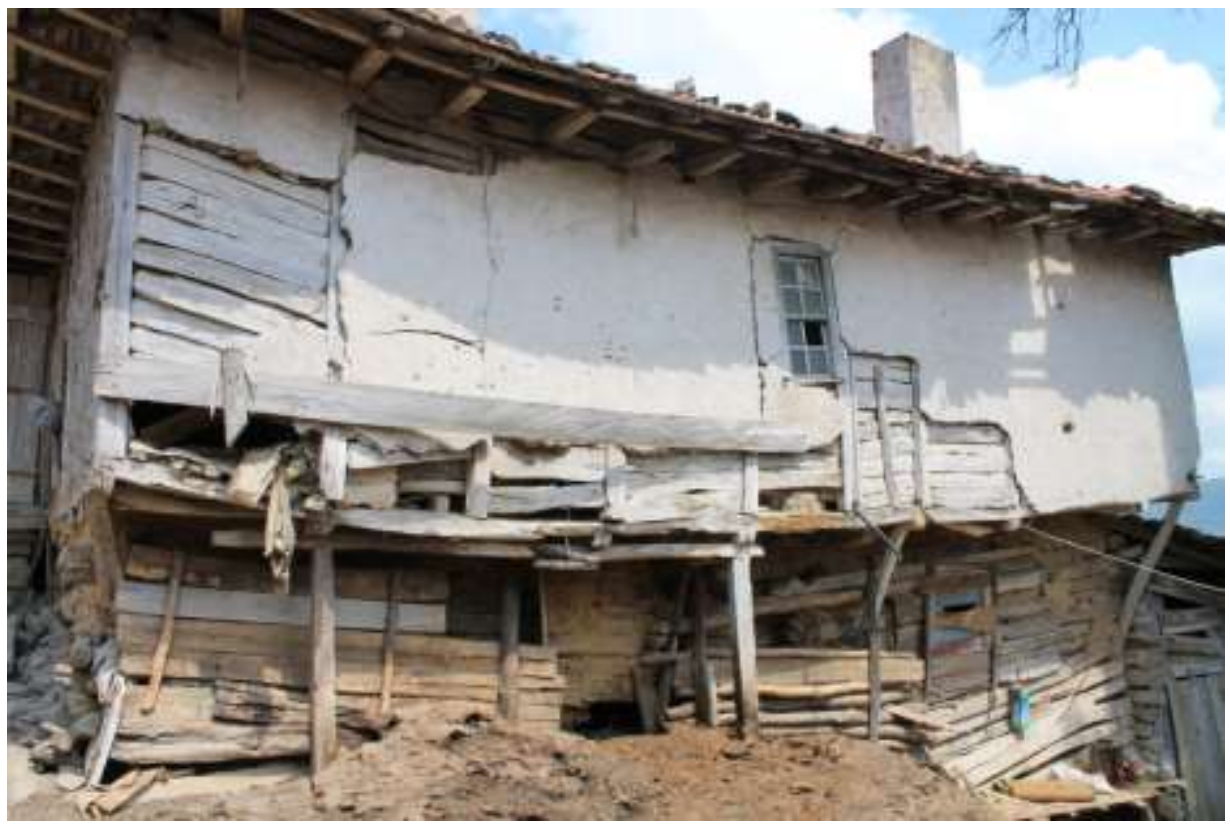

F. 35. Meşelitürkmenler Köyü 4 Nolu Ev 

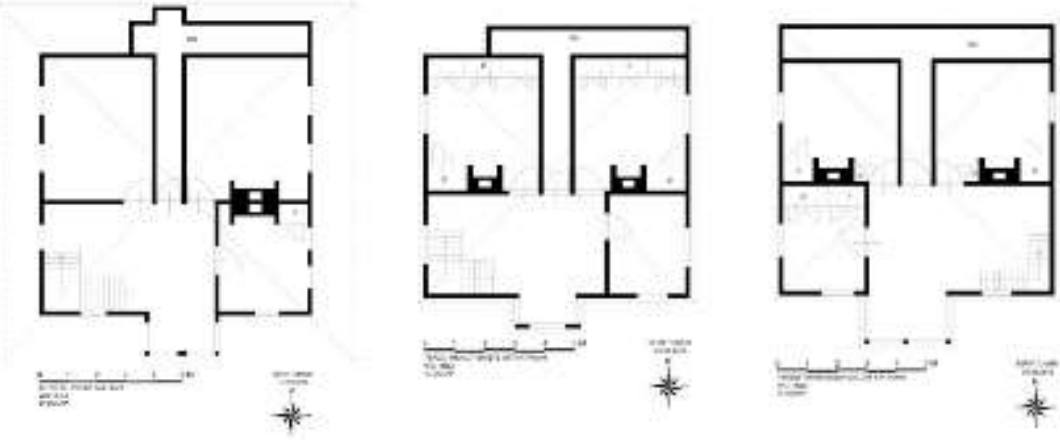

P.1. Terzili Köyü 5 Nolu Ev P.2. Terzili Köyü 2 Nolu Ev P.3. Terzili Köyü 4 Nolu Ev
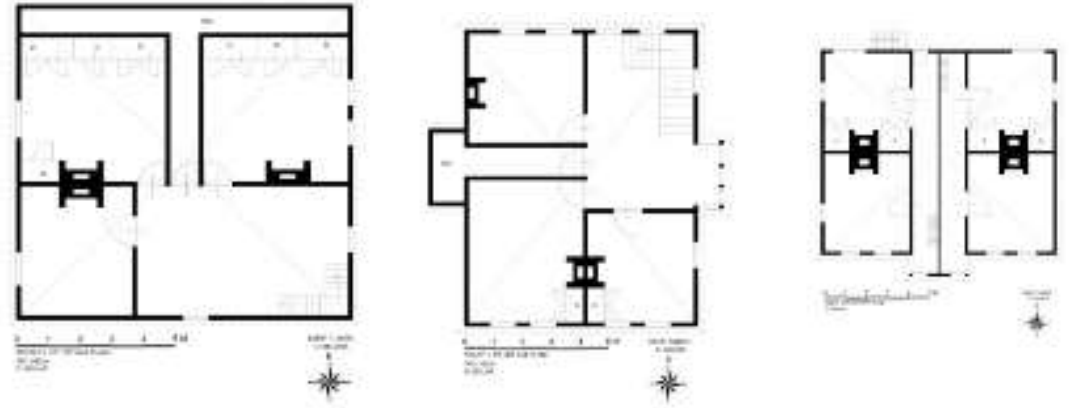

P.4. Terzili Köyü 3 Nolu Ev P.5. Kolay Köyü 1 Nolu Ev P.6. Kolay Köyü 2 Nolu Ev
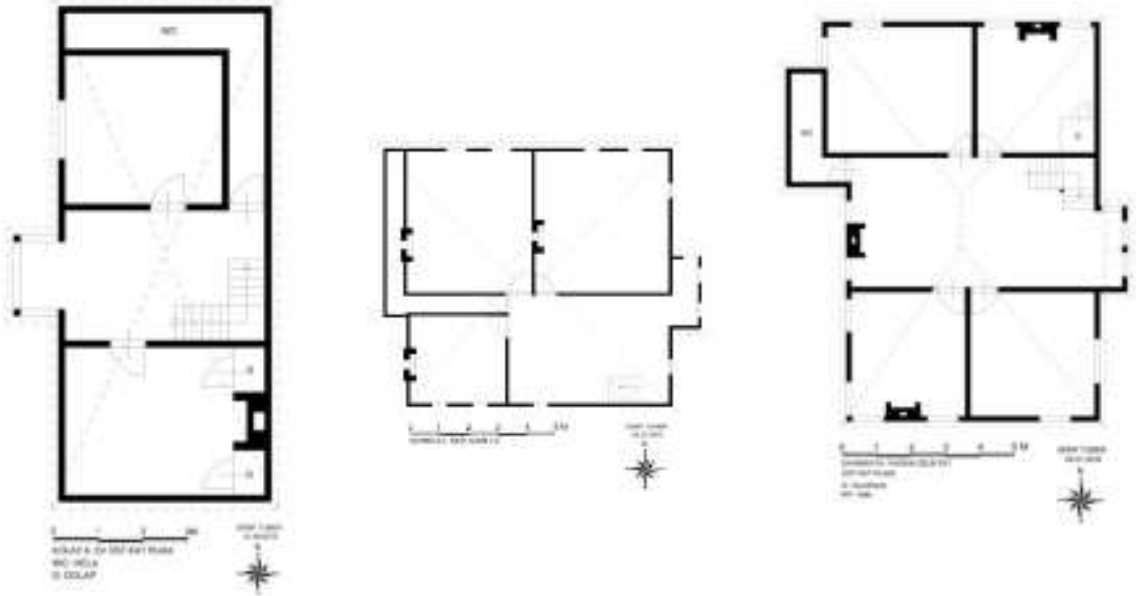

P.7.Kolay Köyü 3 Nolu Ev P.8.Kuzalan Köyü 1 Nolu Ev P.9.Şahinkaya Köyü 1 Nolu Ev 

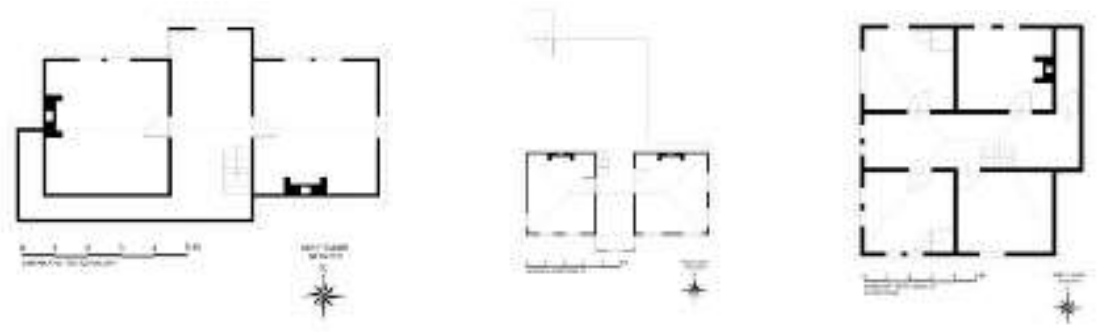

P.10.Şahinkaya Köyü 2 Nolu Ev P.11.Ş.kaya Köyü 3 Nolu Ev P.12.Ş.kaya Köyü 4 Nolu Ev
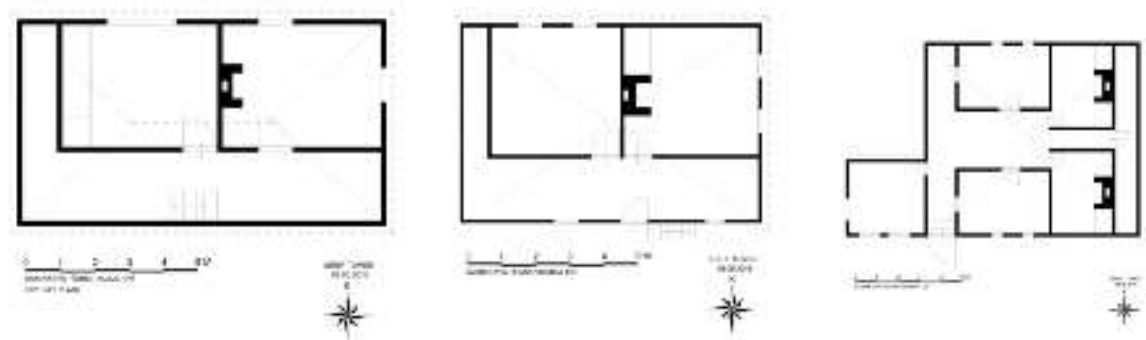

P.13.Ş.kaya Köyü 5 Nolu Ev P.14.Ş.kaya Köyü 6 Nolu Ev P.15.Ş.kaya Köyü 7 Nolu Ev
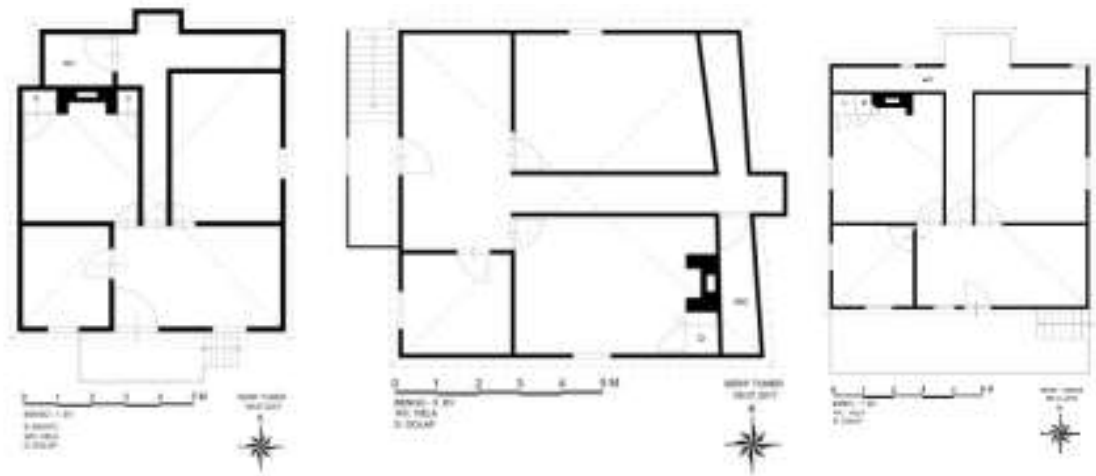

P.16.Bengü Köyü 1 Nolu Ev P.17.Bengü Köyü 2. No.lu Ev P.18.Bengü Köyü 3 No.lu Ev 

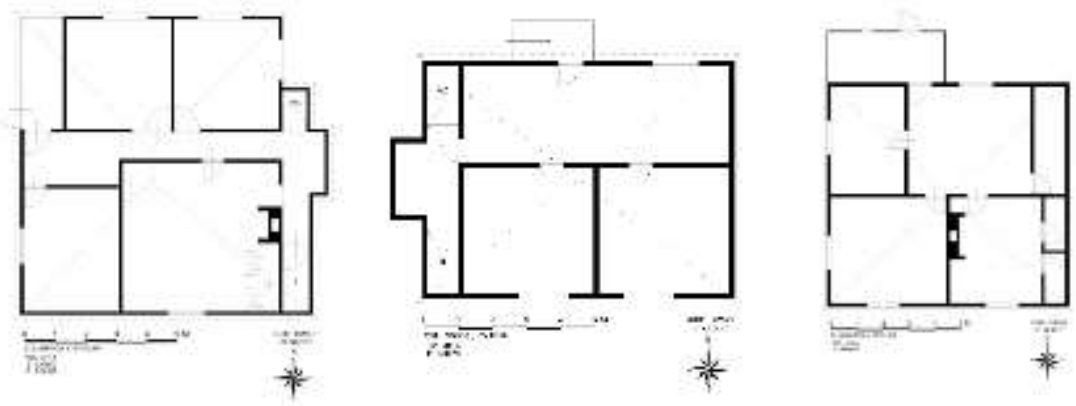

P.19.Çulhakoca Köyü 1 Nolu Ev P.20.Ç.koca Köyü 2 Nolu Ev P.21.Çkoca Köyü 3 Nolu Ev
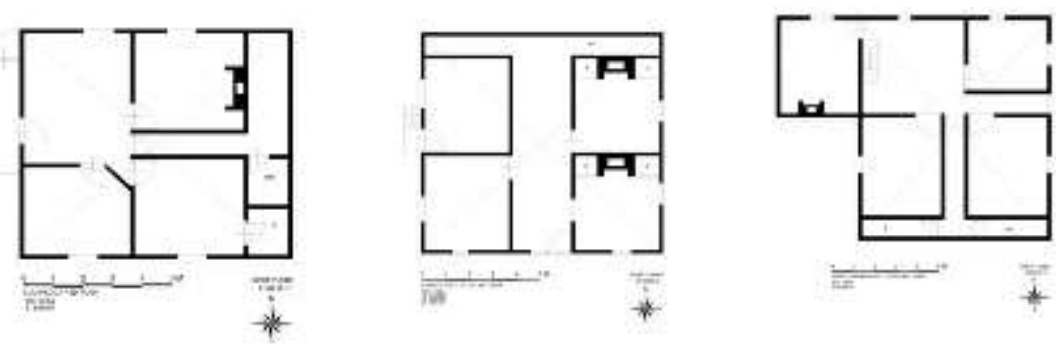

P.22.Ç.koca Köyü 4 Nolu Ev P.23.Karakütük Köyü 1 Nolu Ev24.M.Türkmenler Köyü 1 Nolu Ev

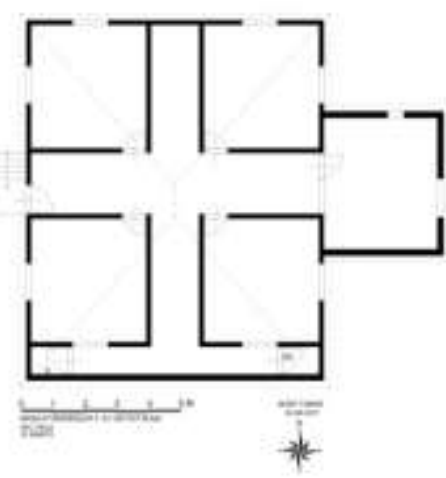

P.25.M.Türkmenler Köyü 3 No.lu Ev

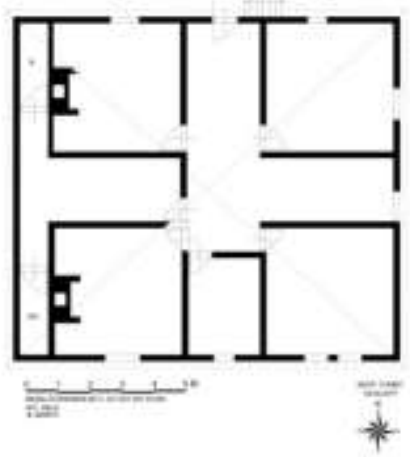

P.26.M.Türkmenler Köyü 4 No.lu Ev 